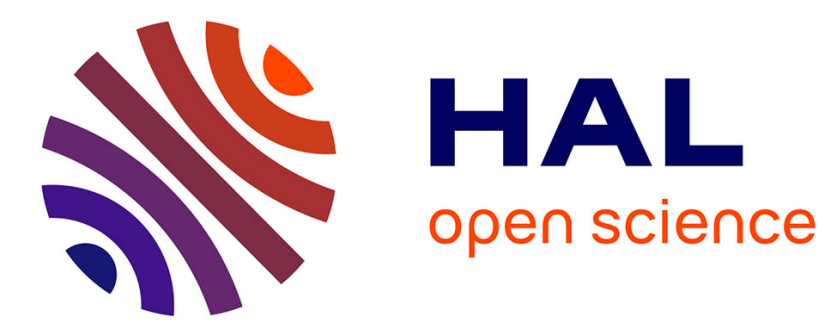

\title{
Reconstructing the total shortening history of the NW Himalaya.
}

\author{
Stéphane Guillot, Eduardo Garzanti, David Baratoux, Didier Marquer, \\ Gweltaz Mahéo, Julia de Sigoyer
}

\section{- To cite this version:}

Stéphane Guillot, Eduardo Garzanti, David Baratoux, Didier Marquer, Gweltaz Mahéo, et al.. Reconstructing the total shortening history of the NW Himalaya.. Geochemistry, Geophysics, Geosystems, 2003, 4(7), pp.1064. 10.1029/2002GC000484 . hal-00103020

\section{HAL Id: hal-00103020 \\ https://hal.science/hal-00103020}

Submitted on 5 Oct 2006

HAL is a multi-disciplinary open access archive for the deposit and dissemination of scientific research documents, whether they are published or not. The documents may come from teaching and research institutions in France or abroad, or from public or private research centers.
L'archive ouverte pluridisciplinaire HAL, est destinée au dépôt et à la diffusion de documents scientifiques de niveau recherche, publiés ou non, émanant des établissements d'enseignement et de recherche français ou étrangers, des laboratoires publics ou privés. 


\section{Reconstructing the total shortening history \\ of the NW Himalaya}

\section{Stéphane Guillot}

Laboratoire de Dynamique de la Lithosphère, CNRS, UCB-Lyon and ENS-Lyon, 2 rue Dubois, 69622

Villeurbanne, France. (sguillot@univ-lyon1.fr)

\section{Eduardo Garzanti}

Dipartimento di Scienze Geologiche e Geotecnologie, Università di Milano-Bicocca, Piazza della Scienza 4, 20126 Milano, Italy.(eduardo.garzanti@mailserver.unimib.it)

\section{David Baratoux}

Laboratoire Dynamique Terrestre et Planétaire, CNRS, 14 Avenue Edouard Belin 31000 Toulouse France. (David.Baratoux@cnes.fr)

\section{Didier Marquer}

Géosciences,CNRS, 16 route de Gray, 25030 Besançon, France. (didier.marquer@univ-fcomte.fr)

\section{Gweltaz Mahéo}

Laboratoire de Dynamique de la Lithosphère, CNRS UMR 5570, UCB-Lyon et ENS-Lyon,

2 rue Dubois, 69622 Villeurbanne, France. (gwelt@alto.univ-lyon1.fr)

\section{Julia de Sigoyer}

Laboratoire de Géologie, CNRS, ENS-Paris, 24 rue Lhomond, 75231 Paris cedex 05, France. (sigoyer@mailhost.geologie.ens.fr)

[1] The onset of India-Asia contact can be dated with both biostratigraphic analysis of syncollisional sedimentary successions deposited on each side of the Indus Suture zone, and by 
radiometric dating of Indian crustal rocks which have undergone subduction to great depths in the earliest subduction-collision stages. These data, together with paleomagnetic data show that the initial contact of the Indian and Asian continental margins occurred at the Paleocene/Eocene boundary, corresponding to $55 \pm 2$ Ma. Such dating, which is consistent with all available geological evidence, including the record of magnetic anomalies in the Indian ocean and decrease of magmatic activity related to oceanic subduction can thus be considered as accurate and robust. The sedimentary record of the Tethys Himalaya rules out obduction of oceanic allochtons directly onto the Indian continental margin during the Late Cretaceous. The commonly inferred Late Cretaceous ophiolite obduction events may have thus occurred in intra-oceanic setting close to the Asian margin before its final emplacement onto the India margin during the Eocene. Granitoid and sedimentary rocks of the Indian crust, deformed during Permo-Carboniferous rifting, reached a depth of some $100 \mathrm{~km}$ about $1 \mathrm{Myr}$ after the final closure of the Neo-Tethys, and began to be exhumed between 50 and $45 \mathrm{Ma}$. At this stage, the foreland basin sediments from Pakistan to India show significant supply from volcanic arcs and ophiolites of the Indus Suture Zone, indicating the absence of significant relief along the proto-Himalayan belt. Inversion of motion may have occurred within only 5 to $10 \mathrm{Myr}$ after the collision onset, as soon as thicker and buoyant Indian crust chocked the subduction zone. The arrival of thick Indian crust within the convergent zone 50$45 \mathrm{Myr}$ ago led to progressive stabilization of the India/Asia convergent rate and rapid stabilization of the Himalayan shortening rate of about $2 \mathrm{~cm} \cdot \mathrm{yr}^{-1}$. This first period also corresponds to the onset of terrestrial detrital sedimentation within the Indus Suture zone and to the Barrovian metamorphism on the Indian side of the collision zone. Equilibrium of the Himalayan thrust belt in terms of amount of shortening vs amount of erosion and thermal stabilization less than $10 \mathrm{Myr}$ after the initial India/Asia contact is defined as the collisional regime. In contrast, the first 5 to $10 \mathrm{Myr}$ corresponds to the transition from oceanic subduction to continental collision, characterized by a marked decrease of the shortening rate, onset of aerial topography, and progressive heating of the convergent zone. This period is 
defined as the continental subduction phase, accommodating more than $30 \%$ of the total Himalayan shortening.

Keywords:, Himalaya, Tectonics, Metamorphism, Sedimentology, Paleomagnetism, Subduction, Collision.

\section{Introduction}

[2] The India-Asia collision, which gave rise to the Himalaya has been one of the most prominent geologic events in the Cenozoic. This collision had a profound impact on global climates and environments, greatly affecting atmospheric and oceanic circulations and floral to faunal distribution [Jaeger et al., 1989]. It probably also changed the asthenospheric circulation as recent tomography data argue for a deep subduction of the Indian lithosphere down to the transition zone [Van der Voo et al., 1999]. These authors suggest that between 1000 and $1500 \mathrm{~km}$ of Indian lithosphere have been subducted since the onset of India-Asia contact. In contrast, reconstruction of the initial geometry of the Indian crust shows that $\sim 670$ $\mathrm{km}$ of shortening have been accommodated at the scale of the Himalayan belt [e.g. DeCelles et al., 2002]. This suggests that the Himalayan shortening has been underestimated or that a part of the Indian upper crust has been early subducted with the rest of the Indian lithosphere. The occurrence of Early Eocene eclogites in the NW Himalaya [Pognante et Spencer, 1991; Guillot et al., 1997] clearly suggests that the distal part of the Indian continental margin was subducted and consequently the amount of shortening estimated by surface reconstruction is underestimated.

[3] The first aim of this paper is to give an overview of what occurred before and during the initial India-Asia contact from the Upper Cretaceous to the Early Eocene. The analysis of sedimentary processes, tectono-metamorphic processes, and paleomagnetic data at the end of 
this period, allow us to define the concept of continental subduction. Then, the comparison of the stratigraphic record of the Eocene to Miocene foreland basins, the thermal evolution of the Indian crustal slices involved during the collision, and the amount of shortening accommodated within the growing orogen will be analyzed to discuss the concept of continental collision.

\section{The Northwestern Himalayan belt.}

[4] In NW Himalaya, the complete evolution of the Himalayan belt from the Upper Cretaceous to the present-day is well preserved in both shallow (sedimentary) and deep (metamorphic) structural levels. The Himalaya rises abruptly from the Indo-Gangetic plain to high mountain peaks south of the Indus suture zone. The main tectonic units can be followed continuously in Western India from the south to the north (Figure 1). The north-dipping Main Frontal thrust (MFT) places the sub-Himalayan molasse belt over underformed Indo-Gangetic foreland basin sediments. The Main Boundary Thrust (MBT), active since at least $10 \mathrm{Ma}$ [Burbank et al., 1996], places the Lesser Himalaya over the sub-Himalayan molasse. The Lesser Himalaya includes a 10 to $15 \mathrm{~km}$ thick section of Precambrian metasediments metamorphosed from low-grade to amphibolite facies metamorphic conditions [Le Fort, 1989]. The north-dipping Main Central Thrust (MCT), active since about 25-20 Ma [e.g., Hodges et al., 1996], places the 10 to $15 \mathrm{~km}$ thick Higher Himalayan Crystallines (HHC) over the Lesser Himalaya (Figure 2). The HHC comprise Precambrian basement and Paleozoic cover rocks metamorphosed during the Oligo-Miocene and intruded by Miocene leucogranites [Searle et al., 1992]. In western India, the Zanskar Shear Zone (ZSZ; western continuation of the South Tibetan Detachment system; Herren, 1987], separates the HHC from Late Precambrian to Eocene sediments of the Tethys Himalaya (Figure 1). This latter represents the shelf facies along the northern Indian continental margin [Gaetani and Garzanti, 1991], onto which the Spontang ophiolite was emplaced. North of the MCT, the Tethys 
Himalaya is invariably detached at its base, suggesting an early decoupling of the sedimentary cover from its basement (Figure 4 in Guillot et al., 2000). The Precambrian to Orovician Haimanta formation crops out below the Tethys Himalayan cover and is generally considered as the northward prolongation of the HHC [Vannay and Grasemann, 1998] (Figure 2). However, Chawla et al. [2000] showed that this metamorphic unit is cross-cut by an underformed Ordovician granite suggesting that this unit is preserved from the Himalayan Tertiary metamorphism. The Tso Morari dome, that recorded the initial subduction of the Indian margin at $55 \pm 7 \mathrm{Ma}$ [de Sigoyer et al., 2000], is sandwiched within the low-grade to amphibolitic Paleozoic metasediments. Finally, the Indus Suture Zone, squeezed between the Tso Morari dome and the Ladakh arc batholith, includes Indian continental slope and rise sediments (Lamayuru Formation; Bassoullet et al., 1983), slices of ophiolite mélange and Cretaceous blueschists together with Cretaceous to Paleogene forearc basin sediments (Figure 1) [Garzanti and Van Haver, 1988].

\section{Tethys during the Cretaceous}

[5] The northward motion of the Indian Plate since the mid-Lower Cretaceous was responsible for the progressive closure of the Neotethys Ocean [Dercourt et al., 1993]. The Indus Suture Zone in western Ladakh includes two Tethyan paleo-subduction zones, beneath the Asian active margin and in a north-dipping intra-oceanic settings respectively [Reuber et al., 1987; Corfield et al., 1999; Mahéo et al., 2000; Roberston et al., 2000]. The subduction beneath the Asian active margin is well documented by the Dras calc-alkaline arc and the Ladakh-Kohistan batholith. This active margin represents a part of the greater TransHimalayan arc extending from Makran to southern Tibet [Beck et al., 1996]. All along this active continental margin, magmatism started synchronously at around 100-110 Ma [Debon et al., 1986]. The intra-oceanic subduction zone also observed from western Pakistan to southern 
Tibet was active between 110 and 130 Ma [Beck et al., 1996; Gnoss et al., 1997; Aitchison et al., 2000].

[6] The ophiolite obduction on the eastern part of the Tethys remains an unsolved complex problem. Emplacement of the Pakistan ophiolites took place either during Late Cretaceous time (ca 85 Ma; Beck et al., 1996) or at the Paleocene-early Eocene boundary (ca 65 to 50 Ma; Qayyum et al., 2001). The former interpretation assumes coupling between India and Africa-Arabia [e.g., Beck et al., 1996], although the two continental masses had been separated since mid-Jurassic times [e.g., Norton and Sclater, 1979; Molnar et al., 1988]. The latter relies on the occurrence of late Maastrichtian fossils in tectonic mélanges beneath the ophiolites, unconformably overlapped by lower Eocene sediments [Allemann, 1979].

[7] We assert that the Late Cretaceous ophiolite obduction took place either onto the Western Pakistan margin by transform movements caused by more rapid northward drift of the Indian Plate with respect to the adjacent Arabian Plate (Fig. 3), or in intra-oceanic settings far to the north, possibly in proximity to the Transhimalayan subduction zone. This hypothesis is supported by the docking of the Kohistan arc to the south Karakorum margin (south Asian margin) during the Upper Cretaceous [Treloar et al., 1996]. Similarly, in the Ladakh-Zanskar area (NW India), slices of arc-related lavas probably coming from the Spongtang-Nidar ophiolite and metamorphosed under blueschist conditions have been recently described in the Sapi-Shergol mélange [Mahéo, unpublished data]. As the Sapi-Shergol mélange corresponds to an accretionary wedge developed during the Upper Cretaceous in front of the south Asian subduction zone [Roberston et al., 2000], this suggests that the intra-oceanic arc represented by the Spontang-Nidar ophiolite was incorporated into the Asian margin during Late Cretaceous time. Moreover, the stratigraphic record of the Tethys Himalaya indicates that the early obduction event did not directly involve the India passive continental margin during the Cretaceous. The major tectono-eustatic transgressive episode took place during mid- 
Cretaceous time (late Albian to early Turonian; 98 to $91 \mathrm{Ma}$ ), at the end of rift-related volcanism and final detachment of India from Gondwana [Garzanti, 1999]. Pelagic oozes were next deposited in constant to gradually decreasing water depths until the early Maastrichtian, when a thick, upward-shallowing marly to carbonate succession accumulated [Nicora et al., 1987]. This latter stratigraphic unit has been given the inappropriate name «Kangi La Flysch» in the earlier geological survey reconnaissance studies [e.g. Kelemen and Sonnenfeld, 1983]. This name has led some authors to suggest that this "flysch" is related to an early obduction of the Spongtang Ophiolite onto the distal Indian margin [Searle, 1983; Searle et al., 1987].

[8] In contrast, Gaetani and Garzanti [1991] and Premoli Silva et al. [1991] showed that the Maastrichtian "Kangi La Formation" documents (1) progressive shallowing - rather than a «very rapid deepening event» [Searle, 1983] - in a mixed terrigenous/carbonate ramp setting, (2) approximately constant - rather than rapidly increased [Searle et al., 1987] - tectonic subsidence rates and (3) includes bioclasts, mud and quartzose silt to fine-grained sand derived from the Indian craton to the south (Figure 4). The absence of flexural tectonic subsidence and the lack of ophiolitic detritus indicate that these passive margin sediments were definitely not deposited in front of an obducting ophiolite [Kelemen et al., 1988].

[9] Thus, we propose that the Late Cretaceous ophiolite collage event may have taken place in an intra-oceanic setting far to the north of Greater India, possibly in the vicinity of the Transhimalayan subduction zone. The Spongtang ophiolite may have been offscraped during the Cretaceous stage of intra-oceanic subduction either within or at the northern side of Neotethys, and incorporated into the Asian accretionary prism after $88 \pm 5 \mathrm{Ma}$ (age of andesitic arc sequence overlying the Spontang ophiolite, Pedersen et al., 2001). A possible age for the collision of the Ladakh-Kohistan intra-oceanic arc with the Asian margin at $65 \mathrm{Ma}$ could be documented by a change in the velocity of the northward drift of India [Klootwijk et 
al., 1992]. The final emplacement of the Spontang ophiolite onto the outer Zanskar shelf (Indian margin) occurred after the Early Eocene deposition of the Kong Formation [Garzanti et al., 1987].

\section{Timing of India-Asia contact}

[10] The age of the collision onset is extensively debated. In the western Himalaya, the proposed ages range from 65 to 45 . The discrepancies between the inferred ages result from the use of different approaches and has consequences on the definition of continent-continent collision. Therefore, the sequence of the early orogenic events, from the first compressional deformation related to the initial subduction of the thin Indian margin, to final docking and rapid rise of the Himalayan range is still poorly understood. In the present paper, initial IndiaAsia contact is defined as the time when the edge of the Indian continent first arrived at the Kohistan-Transhimalaya trench, leading to the complete consumption of the Neotethys lithosphere, followed by continental subduction.

[11] The first India-Asia contact has been proposed at $65 \mathrm{Ma}$, based on significant lithospheric plate reorganization in the Indian ocean [Courtillot et al., 1986], evidence for the first India-Asia faunal exchange [Jaeger et al., 1989] and possible initiation of deformation in the Indian margin with emplacement of a tectonic mélange [Searle, 1983; 1987; Beck et al., 1996]. Paleomagnetic data from the Indian oceanic floor also record variations in the direction and in the velocity of the Indian plate motion at about 65 Ma [Klootwijk et al., 1992]. In the same way, the continental contamination described in the magmatism of the south Asian margin was related to the subducted Indian margin at about $60 \mathrm{Ma}$ in Ladakh [Searle et al., 1987]. However, at this time, the Indian continent was located at about 1500 to $2000 \mathrm{~km}$ south of the Asian margin [Besse and Courtillot, 1988], which precludes an initial India-Asia contact at this time. Nevertheless, an initial Cretaceous-Paleocene Indian collision with the 
Kabul block on the western part and the Kohistan-Ladakh arc is possible [Treloar and Coward, 1991]. Such an Early Paleocene contact could explain the onset of terrestrial fauna exchange between Asia and India at that time [Jaeger et al., 1989].

[12] In contrast, Dewey et al. [1989] and Le Pichon et al. [1992] suggest that the continental collision occurred during the Middle Eocene, at about 45 Ma. Such an age for the initial collision is incompatible with both the early foreland-basin stratigraphic record from Pakistan to Nepal, dominated by early Eocene detrital sediments from volcanic arc and ophiolites [Critelli and Garzanti, 1994; DeCelles et al., 1998; Najman and Garzanti, 2000] and with ultra high pressure metamorphism recorded at 55-45 $\mathrm{Ma}$ in the leading edge of the Indian plate. Klootwijk et al. [1992] and Acton [1999] correlated the sharp slowdown of spreading at 55+ Ma documented by magnetic anomalies on the Indian ocean floor with the true initial contact between India and Asia in the NW Himalaya. According to Besse et al. [1984], this was followed by a progressive eastward suturing between 50 and 40 Ma. Treloar and Coward [1991] and Rowley [1996], according to sedimentologic constraints, also argued that the collision first occurred in the western syntaxis at about 55-50 Ma and then at about 50-45 Ma in the central and eastern part of the range.

[13] A continuous record of transition from passive margin to collisional basin sedimentation is documented by accurately dated stratigraphic sections from the Higher Himalaya (Figure 4) [e.g., Baud et al., 1985; Nicora et al., 1987]. The major Late Paleocene (ca $55 \pm 1$ Ma, conversion to Ma according to the Berggren et al., 1995 time scale) shallowing event in the distal part of the Indian margin was marked by an abrupt transition to peritidal dolostones. It was interpreted as flexural uplift related to initial contact of India and Asia [Garzanti et al., 1987]. The occurrence of debris flow conglomerates with limestone pebbles ranging from the Late Cretaceous to the Late Paleocene [Fuchs, 1987] also indicates that the onset of deformation is very close to the Paleocene/Eocene boundary (Figure 4). 
[14] The sedimentary records of the Tethys Himalaya passive margin and the Transhimalayan active margin bear nothing in common from Cretaceous to Paleocene times, but begin to be closely comparable since the beginning of the Eocene, documenting the final closure of the Tethys between 55 and $50 \mathrm{Ma}$. Indeed, shallow-marine limestones yielding the Earliest Eocene nummulites (P6 to P7 zones, ca 54 to $51 \mathrm{Ma}$ ) are found on both sides of the Indus suture, from the distal Indian margin to the Transhimalaya forearc basin [Baud et al., 1985]. In Pakistan and in India, Early Eocene marine sediments were replaced by continental redbeds [Garzanti et al., 1987; Garzanti and Van Haver, 1988]. This continental redbeds unconformably overlying the Indian passive margin is characterized by the abrupt appearance of ophiolitic and volcanic detritus followed by arkosic detritus from the dissected roots of the Transhimalayan arc in fanglomerates capping the Indus forearc basin succession. This detrital sedimentation suggests the final closure of Tethys and active uplift of the Transhimalaya arctrench system and ophiolitic rocks of the Indus suture by 50 Ma (Figure 4) [Garzanti et al., 1996]. As the initial Late Paleocene-Early Eocene contact took place at a low latitude of ca $8^{\circ} \mathrm{N}$, the closure of the Neotethys determined an abrupt shift towards more arid climates, as documented by local evaporites and caliche paleosoils in continental redbeds [Garzanti et al., 1987].

\section{The early collisional evolution}

[15] During the Early Eocene, suture-derived detritus replaced quartzose detritus fed from the Indian continent in the south during the whole Mesozoic and Paleocene (figure 4) [Nicora et al., 1987; DeCelles et al., 1998]. Stratigraphic dating of such a marked petrographic change represents the most accurate and reliable direct way to establish the precise age of final closure of the Neotethys, and to document its possible diachroneities in various segments of the future Himalaya [Rowley, 1996]. Farther to the south, the Eocene-Oligocene clastic 
sediments observed on the Owen Ridge and presumed to represent the lower part of the Indus Fan include detrital K-feldspars with lead isotopic signatures pointing to an arc source in the Indus Suture Zone [Clift et al., 2000]. All provenance information thus consistently suggests that relief existed only on the northern side of the Indus suture zone in NW Himalaya in the earliest collisional stages. In contrast, the provenance data from Middle Eocene in Nepal indicate that Tethyan rocks were probably exposed and holding up relief south of the suture zone by that time [DeCelles et al., 1998; Robinson et al., 2001].

[16] The Early Thanetian to Lower Eocene units are capped by extensive lateritic paleosols throughout northern Pakistan, India and Nepal, documenting prolonged exposure of sediments and lack of significant subsidence during most of the late Eocene to the Oligocene [Pivnik and Wells, 1996; DeCelles et al., 1998]. Such a long stage of negligible sediment accumulation from about $50 \mathrm{Ma}$ to $25 \mathrm{Ma}$ - has been related either to a transition from the low-strength collision (subduction of the thinned Indian continental-margin crust) to high-strength collision (underthrusting within the collision zone zone by unstretched Indian crust; Najman and Garzanti 2000) or to southward migration of the flexural bulge [DeCelles et al., 1998]. If the latter hypothesis is correct, the underlying syn-collisional sediments would represent backbulge deposits. In addition, most of the sediment volume deposited in the main foredeep depozone of the foreland basin system would not be preserved anywhere along the Himalayan range, excepting perhaps the limited outcrops of Lower Eocene redbeds in the Tethys Himalaya of Zanskar and southern Tibet [Garzanti et al., 1987; Willems et al., 1996]. A huge volume of clastic sediments was inferred to have been derived from the rising Himalaya and deposited from the Late Eocene to the Early Miocene in remnant-ocean basins from Katawaz to Makran. This deltaic to turbidite system might have represented the major depocenter of orogenic sediments derived from the Himalayan uplands at a stage of general bypassing and westward axial transport [Qayyum et al., 2001]. 
[17] The Balakot redbeds widely exposed in the Hazara re-entrant, was previously thought to represent an up to $8 \mathrm{~km}$-thick continuous stratigraphic succession of the Early to Middle Eocene age [Bossart and Ottiger, 1989]. Recently Najman et al. [2001] showed that the Balakot formation contains micas with Oligocene detrital $\mathrm{Ar} / \mathrm{Ar}$ ages. There is thus no apparent exception to the limited thickness of the early collisional foreland basin sediments along the Himalaya, documenting a very low subsidence related to a low flexural bulge.

[18] Since the latest Oligocene, renewed foreland basin subsidence $\left(>0.2 \mathrm{~mm} \cdot \mathrm{yr}^{-1}\right)$ was associated with thrusting and accretion of the Himalayan orogenic wedge and characterized by thick, fine-grained terrigenous successions with metamorphic grade steadily increasing in time from a very low grade (pre-Himalayan) to a low grade clatic sediments (Himalayan overprint). The youngest metamorphic imprint is revealed by the wealth of slate to phyllite lithics suddenly supplied to the Pakistan and Indian foreland region [Critelli and Garzanti, 1994; Najman and Garzanti, 2000], which yield detrital micas with metamorphic Ar/Ar ages of 36-40 Ma [Najman et al., 2001] and 28-25 Ma [Najman et al., 1997], respectively (figure 4). Metamorphic grade of lithic fragments reached the garnet zone. These garnet-bearing micaschists were tectonically exhumed and eroded around $22 \mathrm{Ma}$, as indicated by the cooling ages of detrital micas within the Kasauli and Dharamsala Formations [Najman et al., 1997; Najman and Garzanti, 2000]. These events may record motion along the Main Central thrust, with unroofing of Himalayan metamorphic rocks and active till the deposition of the Lower Dharamsala Formation at 17 Ma (Figure 4) [White et al., 2000].

\section{Timing of the Early Himalayan metamorphism}

[19] In NW Pakistan, two distinct phases of the early metamorphism are distinguished (Figure 5). The eclogitic event $\left(>25 \mathrm{kbar},>600^{\circ} \mathrm{C}\right.$ ) recorded in the Kaghan nappe [Pognante and Spencer, 1991; O'Brien, et al., 2001] and also in the partially preserved eastern part of the 
Nanga Parbat syntaxis [Le Fort et al., 1997] is related to the early subduction of the Indian Plate below the Kohistan-Ladakh arc. The HP granulitic facies metamorphism $(13 \pm 3$ kbar, $750 \pm 50^{\circ} \mathrm{C}$ ) associated with partial melting is related to the thickening of the Indian plate [Treloar et al., 1989; Pognante et al., 1993]. The spatial distinction between the eclogitic and the granulitic units is difficult because they are invariably imbricated within a thrust pile [Treloar et al., 1989]. Tonarini et al. [1993] dated The eclogitic assemblage of Kaghan is dated between between 49 and $46 \mathrm{Ma}$ by Sm/and, U/Pb and SHRIMP methods [Tonarini et al., 1993; Spencer and Gebauer, 1996; Kaneko et al. 2001]. The upper structural levels of the Nanga Parbat massif and Kaghan upper rocks were buried to pressure of c. $10 \mathrm{kbar}$ and heated to temperature of c. $650^{\circ} \mathrm{C}$ at $46-41 \mathrm{Ma}$ [Smith et al., 1994; Zeitler and Chamberlain, 1991; Foster et al., 2002]. Finally, Treloar and Rex [1990], Chamberlain et al. [1991] and Tonarini et al. [1993] showed by $\mathrm{Ar} / \mathrm{Ar}, \mathrm{Rb} / \mathrm{Sr}$ and $\mathrm{U} / \mathrm{Pb}$ thermochronology that cooling below $500^{\circ} \mathrm{C}$ was completed $40 \mathrm{Myr}$ ago (Figure 5). Similar to the Pakistan, two distinct phases of the early metamorphism are temporaly and spatially distinguished in the NW India. The eclogitic event $\left(>25 \mathrm{kbar}, 600 \pm 50^{\circ} \mathrm{C}\right.$ ) is recorded south of the Indus suture zone in the Tso Morari dome (Figure 1) [de Sigoyer et al., 1997; Guillot et al., 1997, O’Brien et al., 2001]. The eclogitic event is dated at $55 \pm 6 \mathrm{Ma}$ by $\mathrm{U} / \mathrm{Pb}, \mathrm{Lu} / \mathrm{Hf}$ and $\mathrm{Sm} / \mathrm{Nd}$ methods [de Sigoyer et al., 2000]. This metamorphic age is interpreted as the initial age of Indian continental subduction beneath the Asian margin [de Sigoyer et al., 2000]. The retrogression under amphibolitic facies metamorphic conditions occurred at $47 \pm 2 \mathrm{Ma}$ according to the $\mathrm{Sm} / \mathrm{Nd}, \mathrm{Rb} / \mathrm{Sr}$ and $\mathrm{Ar} / \mathrm{Ar}$ datings (Figure 5). Moreover, apatite fission track ages of $46 \pm 2 \mathrm{Ma}$ from the Ladakh intrusives in the Kargil area suggest that the area was not affected by any post-Middle Eocene thermal events [Lal and Nagpaul, 1975]. Clift et al. [2002] also report apatite fission track ages ranging between 44 and $27 \mathrm{Ma}$, and Ar/Ar biotite ages of 49-44 Ma for the Ladakh Batholith. 
[20] The low geothermal gradient preserved in the eclogitic units of Kaghan and Tso Morari is clearly related to the subduction of the Indian margin below the Kohistan-Ladakh arc between 55 and $50 \mathrm{Ma}$. In contrast, the first Barrovian metamorphism (HP amphibolitic to granulitic facies conditions) recorded both by the partly exhumed eclogitic unit and by the granulitic unit located close to the suture zone during the Middle Eocene $(\approx 45 \mathrm{Ma})$ is more difficult to explain. This event occurred less than $10 \mathrm{Myr}$ after the initial impingement of India against Asia, while the classical conductive thermal model suggests that a minimum of 20 to 30 Myr is necessary for a previously thickened crust to relax thermally [England and Thompson, 1984].

[21] In NW Himalaya, the first granulitic metamorphic event and the associated crustal melting (50-40 Ma) followed immediately the eclogitic metamorphic event (55-45 Ma). This suggests that these tectono-metamorphic events could be intimately related and related to the breakoff of the subducted India slab during Early to Middle Eocene time [Guillot et al., 1997; Chemenda et al., 2000, Kohn et al., 2002]. This hypothesis is supported by an important remelting of the Ladakh batholith between 50 and $46 \mathrm{Ma}$ [Weinberg and Dunlap, 2000].

[22] Southward, another and younger metamorphic event $\left(11 \pm 3 \mathrm{kbar}, 700 \pm 50^{\circ} \mathrm{C}\right)$ is well preserved in the HHC from Zanskar to Bhutan [e.g. Guillot et al., 1999 for review]. In NW India, the HHC slab is tectonically separated from the Tso Morari dome by the Zanskar synclinorium (Figure 1) and clearly corresponds to a distinct unit (Figure 2). The EoHimalayan metamorphic event recorded by the HHC ranges between 37 and $30 \mathrm{Ma}$ [Searle et al., 1992; Prince et al., 1999]. Moreover, Vance and Mahar [1998] showed that the onset of prograde garnet growth in Zanskar started at about 33 Ma. In the same way, Prince et al. [1999] dated leucosomes from Gahrwal at about $37 \mathrm{Ma}$, suggesting that the HHC was thermally reequilibrated at this time (Figure 5). 
[23] In order to explain the heating recorded by the HHC during the Oligo-Miocene over a short period of time, Guillot and Allemand [2002] have tested, by a two-dimensional thermal model, the time necessary to heat a $10 \mathrm{~km}$ thick continental slice underthust below a high-heat producing zone that could represent the thickened internal Himalayan zone. Guillot and Allemand [2002] have shown that the best way to reproduce the P-T conditions recorded by the HHC is to impose a decoupling in depth of the HHC from the rest of the subducting Indian plate. Such decoupling allows the HHC both to remain at a constant depth and to be heated up. 10 million years were necessary to reach a temperature of $700^{\circ} \mathrm{C}$ in the $\mathrm{HHC}$, while the underthrust Indian plate remained at a relatively low temperature $\left(<600^{\circ} \mathrm{C}\right)$. To preserve high temperature $\left(>600^{\circ} \mathrm{C}\right)$ during the exhumation of the $\mathrm{HHC}$, a high vertical rate

$\left(>3 \mathrm{~mm} \cdot \mathrm{yr}^{-1}\right)$, similar to the present-day uptift rate, was required. This suggests that the MCT and STDS, the tectonic boundaries of the HHC were probably active over a short period of time $(<10 \mathrm{Myr})$ during the Early Miocene, compatible with the short period of leucogranite emplacement and geochronological records of the main MCT activity between 25 and $18 \mathrm{Ma}$ [Hubbard and Harrison, 1989; Guillot et al., 1994; Hodges et al., 1996].

[24] In south Karakorum (NE Pakistan), the discovery of Neogene granulitic rocks associated with migmatites and numerous mantle-derived magmatic rocks (Karakorum Metamorphic Complex) in a setting of global north-south shortening (Rolland et al., 2001) strongly suggests that interaction between the thickened Asian crust and the underlying mantle occurred during the India-Asia convergence. Eastward, in southern Tibet, potassic Neogene magmatism have also been observed (Mahéo et al., 2002). The origin of the south Karakorum granulites and the associated Neogene magmatism all along the southern Tibet are discussed in light of a second slab breakoff of the subducting Indian slab, starting at about 25 Ma [Mahéo et al., 2002].

\section{Modeling of the Himalayan shortening}


[25] According to the available paleomagnetic data, Dewey et al. [1989] and Le Pichon et al. [1992] estimated a total convergence of $2300-2150 \mathrm{~km}$ in the western syntaxis since $45 \mathrm{Ma}$, whereas Molnar and Tapponnier [1975] estimated a total convergence of $3000 \pm 500 \mathrm{~km}$. By backward motion of Asian and Indian lithospheric blocks, Replumaz and Tapponnier [2003] also estimated $3000 \mathrm{~km}$ of convergence if the initial India-Asia contact is at $55 \mathrm{Ma}$.

[26] The Himalayan shortening (south of the Indus suture zone) is estimated by massbalanced cross-sections at $\sim 670 \mathrm{~km}$ from Pakistan to Sikkim [e.g. DeCelles et al., 2002]. By plate reconstruction, Himalayan shortening is estimated at $1250 \pm 250 \mathrm{~km}$ [Achache et al., 1984; Besse et al., 1984; Powell et al., 1988; Dewey et al., 1989; Patzelt et al., 1986; Matte et al., 1997]. This difference is explained by the existence of a Greater India, extended up to $650-700 \mathrm{~km}$, north of the present-day Indus suture zone, and consisting of all of the Indian lithosphere that has been subducted beneath southern Tibet [Klootwijk et al., 1979; Patriat and Achache, 1984; DeCelles et al., 2002]. The existence of the Greater India is compatible with the original fit of the North Indian margin with the North Australian margin at $160 \mathrm{Ma}$ [Powell et al., 1988; Dercourt et al., 1993; Matte et al., 1997]. The existence of a Greater India has important consequences for the earlier evolution of the Himalayan belt and implies that a part of the Indian continental lithosphere was totally subducted before $45 \mathrm{Ma}$. Moreover, if the initial India-Asia contact occurred at $55 \mathrm{Ma}$ rather than at $45 \mathrm{Ma}$, the amount of north-south India-Asia convergence is underestimated in the model of Dewey et al. [1989] and Le Pichon et al. [1992]. In figure 6, we propose to reestimate by balanced crustal crosssection the amount of Himalayan shortening through time taking into account three new facts presented in this manuscript. As discussed above, we assumed first that the initial impingement of India against Asia was at 55 Ma. Second, we took into account the occurrence of Himalayan eclogites showing the subduction of the Indian margin below the southern Tibet to a minimum depth of $100 \mathrm{~km}$. Third, we considered that the Haimanta 
formation is distinct from the HHC. By balanced cross-section, we estimated a minimum Himalayan shortening of about $400 \mathrm{~km}$ between 55 and $40 \mathrm{Ma}$ and a total Himalayan shortening of about $1100 \mathrm{~km}$ beetween $55 \mathrm{Ma}$ and the present-day (Figure 6). These values are largely superior than the previous shortening estimates because it takes into account the earlier subduction of the Indian plate north of the Indus suture zone, and are in the same order as paleomagnetic reconstruction estimates.

[27] In order to independently constrain the amount of convergence accommodated by the Indian plate since the initial India-Asia contact, we used an original method. In the following, the Himalayan shortening is defined as the displacement of India relative to the Indus suture (which itself could be moving). Therfore, the India-Asia convergence is defined as the sum of the Himalayan shortening plus Asian contraction including the lateral extrusion.

[28] In order to interpolate the convergence velocity data at different periods of time, the continental subduction of India beneath Asia is modeled as a two converging block system (figure 7). In this one-dimensional model, we consider the forces per unit length along the $\mathrm{x}$ axis which are applied to India: the force which drives the convergence (D, unit $[\mathrm{Pa} / \mathrm{m}])$, and a force (f unit $[\mathrm{Pa} / \mathrm{m}]$ ) which resists to it (figure 7). The equation of the movement is:

$$
D+f=\rho * L * H \frac{d v}{d t}
$$

where $\mathrm{v}$ is the velocity of convergence, $\mathrm{dv} / \mathrm{dt}$ its time derivative and $\mathrm{L}^{*} \mathrm{H}$ is the sectional area of the system subject to deformation. The force which resists to the collision which comes from various effects (viscous shear, folding, sliding along faults etc...) is approximated by the shear stress $(\tau)$ due to the change of velocity in the vertical direction in a viscous flow:

$$
\tau=\frac{\mu}{2} \frac{d v}{d z}
$$

where $\mu \square$ is the apparent viscosity of the material. Equation (1) writes: 


$$
D+L \tau=\rho L H \frac{d v}{d t}
$$

The derivative of the velocity along the vertical direction scales as $\mathrm{v} / \mathrm{H}$ where $\mathrm{v}$ is the convergence velocity. The convergence between India and Asia extended from $55 \mathrm{Ma}$ to present time. We assume that the thickness and the length of the zone subject to deformation and the driving force are constant over this period of time. Equation (1) becomes:

$$
\frac{d v}{d t}=\alpha v+\beta
$$

where $a$ and $b$ are two constants depending on $\mathrm{L}, \mathrm{H}, \mathrm{D}, \rho$ and on the velocity profile in the vertical direction. The equation (4) can be solved and we obtain an exponential law for the convergent rate:

$$
v=a \exp \left[\frac{b-T}{c}\right]+d
$$

where $\mathrm{T}$ is the time ( 0 is present time, past time is negative). The constants a and $\mathrm{d}$ have the dimension of a velocity $\left[\mathrm{ms}^{-1}\right]$ and $\mathrm{c}$ has the dimension of time; a represents the velocity at $\mathrm{T}$ $=\mathrm{b}, \mathrm{d}$ is the asymptotic velocity, c controls the rate of decrease of the velocity through time. The parameters of this exponential law are computed from data of the convergent velocity by using a least-squares method. Although, this model has very strong assumptions (constant driving force and length scale for the deformed area, viscous deformation as the resisting force to the convergence), we think that it provides the best simple analytical form in order to interpolate the velocities of convergence.

[29] According to the available paleomagnetic data [Patriat and Achache, 1984; Courtillot et al., 1986; Besse and Courtillot, 1988; Dewey et al., 1989; Klootwijk et al., 1992; De Mets et al., 1990; Acton, 1999], reconstructions of the motion of India with respect to Eurasia allow to distinguish 4 periods since $65 \mathrm{Ma}$ : 
1- anomaly 30 ( $\sim 65 \mathrm{Ma})$ to anomaly 24 (55 Ma): very fast convergence of about $18 \pm 5 \mathrm{~cm} . \mathrm{yr}^{-}$ 1

2- anomaly 24 ( $\sim 55 \mathrm{Ma})$ to anomalies 22-21 (51-49 Ma) : sharp slowdown from $18 \pm 5 \mathrm{~cm}$.yr ${ }^{-}$

${ }^{1}$ to $10 \pm 2 \mathrm{~cm} \cdot \mathrm{yr}^{-1}$;

3- anomalies 22-21 (51-49 Ma) to anomaly 18 (43 Ma) : progressive decrease down to $6.0 \pm$ $1 \mathrm{~cm} \cdot \mathrm{yr}^{-1}$

4- reorganization of Indian ocean spreading leading to the $4.5 \pm 0.5 \mathrm{~cm} . \mathrm{yr}^{-1}$ convergent velocity from 20 Ma until present.

[30] According to these data, we constructed a curve for the India/Asia convergence (Figure 8). The fitting of these data allow us to estimate numerically the parameters a,b,c,d (Table 1).

\begin{tabular}{|l|l|l|l|l|}
\hline & a & b & c & d \\
\hline Mean & $3.76 \mathrm{~cm} \cdot \mathrm{yr}^{-1}$ & $4.7 \mathrm{Myr}$ & $0.180 \mathrm{Myr}^{-1}$ & $4.5 \mathrm{~cm} \cdot \mathrm{yr}^{-1}$ \\
\hline Fast & $0.99 \mathrm{~cm} \cdot \mathrm{yr}^{-1}$ & $3.8 \mathrm{Myr}$ & $0.178 \mathrm{Myr}^{-1}$ & $5.0 \mathrm{~cm} \cdot \mathrm{yr}^{-1}$ \\
\hline Slow & $5.58 \mathrm{~cm} \cdot \mathrm{yr}^{-1}$ & $5.2 \mathrm{Myr}$ & $0.184 \mathrm{Myr}^{-1}$ & $4.0 \mathrm{~cm} \cdot \mathrm{yr}^{-1}$ \\
\hline
\end{tabular}

Table 1: Computed values of the parameters used to determine the India-Asia convergence and the associated velocity.

Then, the integration of these parameters within equation 3 allow a numerical estimate of the amount of north-south convergence recorded by the India/Asia suture and the correspondent rate, for different selected periods (Table 2). The uncertainties are quoted at $1 \sigma$.

\begin{tabular}{|l|l|l|}
\hline Period & Total convergence & Rates \\
\hline $55 \mathrm{Ma}->50 \mathrm{Ma}$ & $670 \pm 166 \mathrm{~km}$ & $13.4 \pm 3.3 \mathrm{~cm} \cdot \mathrm{yr}^{-1}$ \\
\hline $50 \mathrm{Ma}->40 \mathrm{Ma}$ & $703 \pm 116 \mathrm{~km}$ & $7.0 \pm 1.2 \mathrm{~cm} \cdot \mathrm{yr}^{-1}$ \\
\hline $40 \mathrm{Ma}->20 \mathrm{Ma}$ & $945 \pm 110 \mathrm{~km}$ & $4.7 \pm 0.6 \mathrm{~cm} \cdot \mathrm{yr}^{-1}$ \\
\hline $20 \mathrm{Ma}->0 \mathrm{Ma}$ & $897 \pm 103 \mathrm{~km}$ & $4.5 \pm 0.5 \mathrm{~cm} \cdot \mathrm{yr}^{-1}$ \\
\hline
\end{tabular}




\begin{tabular}{|l|l|l|}
\hline $55 \mathrm{Ma}->0 \mathrm{Ma}$ & $3215 \pm 496 \mathrm{~km}$ & $5.8 \pm 0.9 \mathrm{~cm} \cdot \mathrm{yr}^{-1}$ \\
\hline $45 \mathrm{Ma}->0 \mathrm{Ma}$ & $2140 \pm 271 \mathrm{~km}$ & $4.7 \pm 0.6 \mathrm{~cm} \cdot \mathrm{yr}^{-1}$ \\
\hline
\end{tabular}

Table 2: North-south India/Asia convergence and associated rates computed with the data of the Table 1.

[31] If the initial India-Asia contact occurred at $45 \mathrm{Ma}$, we estimate a total India-Asia convergence of $2140 \pm 271 \mathrm{~km}$, similar to the Dewey et al. [1989] and Le Pichon et al. [1992] estimates. Similarly, the $3215 \pm 496 \mathrm{~km}$ of convergence estimated since $55 \mathrm{Ma}$ (Table 3 ) is in the same order with the $3000 \pm 500 \mathrm{~km}$ of convergence calculated by Molnar and Tapponnier [1975]. As we demonstrate that the initial India-Asia contact occurred at 55 Ma rather than 45 Ma (see discussion above), an excess of $1000 \mathrm{~km}$ of convergence has been accommodated during the first $10 \mathrm{Myr}$ and confirms the existence of the Greater India. It is also noticeable that the inflexion point of the velocity curves is located between 50 and $43 \mathrm{Ma}$ in our model, i.e. very close to the supposed timing of collision at 45 Ma proposed by Dewey et al. [1989] and Le Pichon et al. [1992]. Thus, our preliminary conclusion is that the collision classically defined in the literature at $45 \mathrm{Ma}$ corresponds in our modeling to the stabilization of the India/Asia convergent rate, 10 million years after the initial contact.

[32] In order to calculate the amount of shortening recorded only in the Himalayan belt (the Indian side of the convergent zone) by the equation (3), we fixed the following boundary conditions. We first assumed that during the initial India-Asia contact at $55 \mathrm{Ma}$, the Himalayan shortening rate is equal to the velocity of the Indian plate $\left(18 \pm 5 \mathrm{~cm} \cdot \mathrm{yr}^{-1}\right)$. We also fixed the present-day convergent rate within the Himalaya belt at $2 \mathrm{~cm} . \mathrm{yr}^{-1}$ [Bilham et al., 1997]. Second, in order to estimate the Himalayan shortening rate per selected periods, we impose a total Himalayan shortening ranging between 1100 and $1600 \mathrm{~km}$ (Figure 9) deduced from the initial geometry of the Greater India (Figure 3) [Dalziel et al., 1987; Dercourt et al., 1993; DeCelles and DeCelles, 2001] and tomographic data [Matte et al., 1997; Van der Voo 
et al., 1999]. The difference between the total India-Asia convergence (Table 2) and the calculated Himalayan shortening (Table 4) corresponds to the total amount of shortening accommodated by the Asian plate (Table 5).

\begin{tabular}{|l|l|l|l|l|}
\hline & a & b & c & d \\
\hline Mean & $0.82 \mathrm{~cm} \cdot \mathrm{yr}^{-1}$ & $5.0 \mathrm{Myr}$ & $0.6 \mathrm{Myr}^{-1}$ & $2.0 \mathrm{~cm} \cdot \mathrm{yr}^{-1}$ \\
\hline
\end{tabular}

Table 3: Computed values of the parameters used to determine the Himalayan shortening and the associated rate.

\begin{tabular}{|l|l|l|}
\hline Period & Convergence & Velocity \\
\hline $55 \mathrm{Ma}->50 \mathrm{Ma}$ & $345 \pm 140 \mathrm{~km}$ & $6.9 \pm 2.9 \mathrm{~cm} \cdot \mathrm{yr}^{-1}$ \\
\hline $50 \mathrm{Ma}->40 \mathrm{Ma}$ & $210 \pm 70 \mathrm{~km}$ & $2.1 \pm 0.7 \mathrm{~cm} \cdot \mathrm{yr}^{-1}$ \\
\hline $40 \mathrm{Ma}->20 \mathrm{Ma}$ & $400 \pm 20 \mathrm{~km}$ & $2.0 \pm 0.1 \mathrm{~cm} \cdot \mathrm{yr}^{-1}$ \\
\hline $20 \mathrm{Ma}->0 \mathrm{Ma}$ & $400 \pm 20 \mathrm{~km}$ & $2.0 \pm 0.1 \mathrm{~cm} \cdot \mathrm{yr}^{-1}$ \\
\hline $55 \mathrm{Ma}->0 \mathrm{Ma}$ & $1355 \pm 250 \mathrm{~km}$ & $2.4 \pm 0.4 \mathrm{~cm} \cdot \mathrm{yr}^{-1}$ \\
\hline
\end{tabular}

Table 4: Himalayan shortening and associated velocities per selected periods.

[33] By using equation (3), we estimated that the only way for the initial boundary conditions to converge towards a unique numerical solution is that the Himalayan shortening velocity decrease dramatically to $2.1 \mathrm{~cm} \cdot \mathrm{yr}^{-1}$ between 55 and $40 \mathrm{Ma}$. Moreover, if we use the $1100 \mathrm{~km}$ value of the Himalayan shortening, which is regard as the most realistic (DeCelles et al., 2002), the deceleration must happen between 55 and 51 Ma. The fact that the estimated shortening velocity in the Himalaya was already close to the present-day velocity as early as 50-45 Ma suggests that the convergent zone tends towards a steady state in terms of accretionary flux earlier than has classically been suggested (Hodges, 2000]. 


\begin{tabular}{|l|l|l|}
\hline Period & Convergence & Velocity \\
\hline $55 \mathrm{Ma}->50 \mathrm{Ma}$ & $325 \pm 280 \mathrm{~km}$ & $6.5 \pm 5.6 \mathrm{~cm} \cdot \mathrm{yr}^{-1}$ \\
\hline $50 \mathrm{Ma}->40 \mathrm{Ma}$ & $493 \pm 186 \mathrm{~km}$ & $4.9 \pm 1.9 \mathrm{~cm} \cdot \mathrm{yr}^{-1}$ \\
\hline $40 \mathrm{Ma}->20 \mathrm{Ma}$ & $545 \pm 115 \mathrm{~km}$ & $2.7 \pm 0.6 \mathrm{~cm} \cdot \mathrm{yr}^{-1}$ \\
\hline $20 \mathrm{Ma}->0 \mathrm{Ma}$ & $497 \pm 108 \mathrm{~km}$ & $2.5 \pm 0.5 \mathrm{~cm} \cdot \mathrm{yr}^{-1}$ \\
\hline $55 \mathrm{Ma}->0 \mathrm{Ma}$ & $1860 \pm 689 \mathrm{~km}$ & $3.4 \pm 1.25 \mathrm{~cm} \cdot \mathrm{yr}^{-1}$ \\
\hline
\end{tabular}

Table 5: Asian shortening and associated velocity.

[34] Our fitting suggests that $30 \%$ of the total Himalayan shortening $(345 \pm 140 \mathrm{~km})$ was accommodated during the first 5 Myr. During this period, Himalayan shortening was greater than Asian shortening. Moreover, almost $50 \%$ of the total Himalayan shortening $(555 \pm 210$ $\mathrm{km}$ ) was accommodated during the first 15 Myr. This value is higher than the $400 \mathrm{~km}$ estimated by Patriat and Achache [1984] and also by mass-balance reconstruction. This suggests that on the one hand we have overestimated the total Himalayan shortening (1355 \pm $250 \mathrm{~km}$ ) and consequently, the total Himalayan shortening is closer to $1000 \mathrm{~km}$ rather than $1500 \mathrm{~km}$ as previously suggested. On the other hand, this result emphasizes the major role played by the first 5 to 15 million years for Himalayan evolution. As our estimate of the total Asian shortening $(1860 \pm 746 \mathrm{~km})$ is similar to the $1700 \pm 610 \mathrm{~km}$ previously estimated [Tapponnier et al., 1986; Halim et al., 1988], we suggest that we did not overestimate the total Himalayan convergence.

\section{Discussion}

[35] The demonstration that the initial India-Asia contact took place close to $55 \mathrm{Ma}$ rather than at 50 or $45 \mathrm{Ma}$ is crucial to understand of the Himalayan building processes. Fitting of paleomagnetic data, and composition of the early foreland basin deposits derived mainly from arc and ophiolite rocks of the suture zone, show that during the first $5 \mathrm{Myr}$, a large part of the 
thin Indian margin was subducted below the Asian margin without creating high relief on the Himalayan side (Figure 10A). Moreover, the occurrence of marine sediments up to the Late Ypresian $(50 \mathrm{Ma})$ in the Indus suture zone suggests that this first stage occurred mainly below sea level. Our estimate of the amount of shortening shows that $400 \pm 140 \mathrm{~km}$ of Indian crust was subducted during this short period (Figure 10B). It is also noteworthy that during this period, the Himalayan shortening was greater than Asian shortening.

[36] The fact that only a small quantity of deep material is observable at the surface is compatible with the absence of erosion during this period. From a thermal point of view, the facts that the low-temperature eclogitic unit recorded isothermal decompression during this initial period (Figure 5) and that the HHC had not yet reached its maximum temperature also suggest that the thermal equilibrium was not reached. We can conclude that the first $5 \mathrm{Myr}$ in the life of the Himalayan belt, after the initial India-Asia contact at about $55 \mathrm{Ma}$, represent a transitional period, corresponding to the complete subduction of the continental lithophere. Only the Tethys sedimentary cover is decoupled from its basement that is subducted within the mantle wedge [Guillot et al., 2000] (Figure 10A, B). We define this stage as the continental subduction period.

[37] The 50-45 to 25-20 Ma interval corresponds to a major change in the India-Asia convergent rate, Himalayan shortening rate as well as in the sedimentary and metamorphic processes. During this period, the suturing was completed all along the belt [Klootwijk et al., 1992; Rowley, 1996], and $610 \pm 90 \mathrm{~km}$ of Indian margin was accreted within the Himalayan wedge (Figure 10C, D). The transition from the continental subduction period to this new one could correspond to the slab breakoff of the subducted Indian margin leading to the first amphibolitic to granulitic metamorphic event and to a low flexural bulge of the Indian plate. The HHC were progressively underthrust below the Tethys Himalaya (Figure 10B,C). However, this period is characterized by the apparent absence of subsidence, lack of 
deposition, and widespread pedogenesis in the foreland basin. Convincing reasons for this have not been proposed so far. They may include: 1) uplift of the foreland basin due to docking of the subduction zone by arrival of the Indian crust with normal thickness represented by the HHC; 2) subsequent erosion of the main foreland basin depozone and preservation only of the fore bulge

\begin{tabular}{|c|c|c|c|c|}
\hline Stage & $\begin{array}{l}\text { Oceanic } \\
\text { Subduction }\end{array}$ & $\begin{array}{l}\text { Continental } \\
\text { Subduction }\end{array}$ & $\begin{array}{l}\text { Continental } \\
\text { Collision } \\
\end{array}$ & $\begin{array}{l}\text { Steady-State } \\
\text { Collision }\end{array}$ \\
\hline \begin{tabular}{|l} 
Age \\
Crust type \\
\end{tabular} & $\begin{array}{l}>55 \mathrm{Ma} \\
\text { oceanic }\end{array}$ & $\begin{array}{l}55-50 \mathrm{Ma} \\
\text { thin Indian crust }\end{array}$ & $\begin{array}{l}50-25 \mathrm{Ma} \\
\text { normal Indian crust }\end{array}$ & $\begin{array}{l}25-0 \mathrm{Ma} \\
\text { normal Indian crust }\end{array}$ \\
\hline India-Asia velocity & 18 cm.yr-1 & 18 -> 10 cm.yr-1 & $10->4.5 \mathrm{~cm} . \mathrm{yr}-1$ & $4.5 \mathrm{~cm} . \mathrm{yr}-1$ \\
\hline India/Asia convergence & $0 \mathrm{~cm} . \mathrm{yr}-1$ & $670 \pm 166 \mathrm{~km}$ & $1625 \pm 220 \mathrm{~km}$ & $1122 \pm 105 \mathrm{~km}$ \\
\hline Himalayan velocity & 18 cm.yr-1 & $18->2.5$ cm.yr-1 & $2.5->2.0 \mathrm{~cm} . \mathrm{yr}-1$ & $2.0 \mathrm{~cm} . \mathrm{yr}-1$ \\
\hline Himalayan shortening & $0 \mathrm{~km}$ & $345 \mathrm{~km}$ & $510 \pm 80 \mathrm{~km}$ & $500 \pm 25 \mathrm{~km}$ \\
\hline Asian velocity & $0 \mathrm{~cm} \cdot \mathrm{yr}-1$ & $<5$ cm.yr-1 & $<5.0->3.0 \mathrm{~cm} . \mathrm{yr}-1$ & $2.6 \mathrm{~cm} . \mathrm{yr}-1$ \\
\hline Asian shortening & $0 \mathrm{~km}$ & $<250 \mathrm{~km}$ & $493 \pm 186$ & $622 \pm 110$ \\
\hline $\begin{array}{l}\text { Subsidence rate } \\
\text { Sedimentary facies } \\
\text { Sandstone petrography }\end{array}$ & $\begin{array}{l}\sim 0.02 \mathrm{~mm} . \mathrm{yr}-1 \\
\text { shelf sedim } \\
\text { quartzarenites }\end{array}$ & $\begin{array}{l}\sim 0.1 \mathrm{~mm} . \mathrm{yr}-1 \\
\text { deltaic redbeds } \\
\text { volc+ophio detritus }\end{array}$ & $\begin{array}{l}<0.01 \mathrm{~mm} . \mathrm{yr}-1 \\
\text { uncorformities } \\
\text {------ }\end{array}$ & $\begin{array}{l}>0.2 \mathrm{~mm} . \mathrm{yr}-1 \\
\text { fluvial molasse } \\
\text { metam detritus }\end{array}$ \\
\hline $\begin{array}{l}\text { Indian edge metamorph } \\
\text { HHC metamorphism }\end{array}$ & $\begin{array}{l}\text { none } \\
\text { none }\end{array}$ & $\begin{array}{l}\text { eclogite facies } \\
\text { none }\end{array}$ & $\begin{array}{l}\text { amphibolite facies } \\
\text { granulite facies }\end{array}$ & $\begin{array}{l}\text { greenschist facies } \\
\text { anatexis }\end{array}$ \\
\hline Asian Margin & arc volcanism & cont sedim & uplift & uplift \\
\hline
\end{tabular}

Table 6: From subduction to collision dynamics in Himalaya

zone closer to the stable foreland; 3) sediment bypass and/or shift of sediment depocenters elsewhere (Katawaz - Makran - early Indus Fan); 4) very low erosion rates as a result of either still very low mountain relief, or arid climate. It is noteworthy that the Andes for instance appear to be a highly-elevated mountain belt, but scarce detritus is accumulated in the arc-trench systems from Peru to Northern Chile due to pronounced aridity [Montgomery et al., 2001]. A marked shift is documented in the Tethys Himalayan succession from humid equatorial climates at late Paleocene times (pure quartzarenites with quartz pitted in lateritic paleosoils) to more arid conditions in the Early Eocene (local evaporites, caliche paleosols in redbeds). This was apparently related to the closure of the Neotethys, and thus decrease source of humid air masses [Bossart and Ottiger, 1989]. However, why foreland basin 
subsidence is everywhere in the front of the range from $\mathrm{N}$ Pakistan to Nepal very low until about 20 Ma remains a puzzling open question. Deep-water facies were apparently not deposited anywhere in the Himalayan foreland basin, which was always subaerial to very shallow-marine (e.g., base of foreland basin sequence directly alluvial or transitional marine at most, a different situation with respect to other orogens). Whatever the tectonic reason may be, this conclusively points to a very shallow continental subduction angle $\left(<10^{\circ}\right)$.

[38] Progressive thickening of the radiogenic upper Indian crust allowed progressive warming of the internal Himalayan wedge responsible for the Eo-Himalayan metamorphism recorded in the HHC. During this period, the whole Asian plate started to be strongly affected by the India-Asia collision [e.g. Tapponnier et al., 1986; Lacassin et al., 1997; Replumaz and Tapponnier, 2003], suggesting that the stress induced by the India-Asia convergence was progressively transmitted to the hinterland part of the system and the width of the collision zone grew northward with time [Tapponnier et al., 2001]. Since $45 \mathrm{Ma}$, the velocity of northward indentation of the Indian plate became higher than the velocity of Indian plate subduction. This stage corresponds to the onset of the collision as defined by Dewey et al. [1989] and Le Pichon et al. [1992].

[39] Since about 25-20 Ma, progressive southward propagation of the thrust front and thrusting of the Lesser Himalaya below the MCT enhanced the progressive exhumation and erosion of the warm HHC wedge (Figure 10E). Such a rapid exhumation of the thermally relaxed HHC during the Miocene is responsible for their partial decompression melting all along the belt [Harrison et al., 1998; Guillot et al., 1999]. Deposition of thick sequences of alluvial sediments in the foreland basin since the Early Miocene [DeCelles et al., 1998; 2001; Najman and Garzanti, 2000; Najman et al., 2001] and throughout the Miocene [White et al., 2002] document markedly increased erosion and sedimentation rates [Burbank et al., 1996]. At the lithospheric scale, northward indentation velocity of the Indian plate $\left(3 \mathrm{~cm} . \mathrm{yr}^{-1}\right)$ 
became greater than its subduction velocity $\left(2 \mathrm{~cm} \cdot \mathrm{yr}^{-1}\right)$, inducing its progressive steepening and roll over (Figure 10E). We propose that the underthrusting of the Indian crust could be a continuous process with a constant velocity of about $2 \mathrm{~cm} . \mathrm{yr}-1$. since $50-40 \mathrm{Ma}$. In contrast, the tectonic and thermal activities of the metamorphic units such as the HHC were probably a discontinuous processes with long periods of no tectonic activity ( $>10 \mathrm{Myr}$ ) followed by rapid ( $\left.\mathrm{cm} . \mathrm{yr}^{-1}\right)$ and short tectonic activity $(<5 \mathrm{Myr})$ which was balanced by a strong erosion. We propose to define this period ranging between $50 \mathrm{Ma}$ and the present-day as the continental collision period.

\section{Conclusion}

[40] Constraints from stratigraphy, paleomagnetism, geochronology and tectonophysics in the NW Himalaya indicate that the initial India-Asia contact took place very close to the Paleocene/Eocene boundary (55 Ma) after a long period of oceanic subduction. A major decrease in plate velocity (from $18 \mathrm{~cm} \cdot \mathrm{yr}^{-1}$ to $10 \mathrm{~cm} \cdot \mathrm{yr}^{-1}$ ) from $55^{+} \mathrm{Ma}$ to $50 \mathrm{Ma}$ is interpreted as the effect of the India-Asia contact. Final closure of Neotethys was recorded by forced shoaling of marine sediments in Zanskar at the Paleocene/Eocene boundary (55 $\pm 0.5 \mathrm{Ma})$, followed in the late Ypresian (50 Ma) by deposition of deltaic sediments derived from arc and ophiolite rocks incorporated in the obducted Asian accretionary prism. Petrography of foreland basin clastics indicates that marine seaways between India and Asia did not exist anymore at that time, and that major relief formed only on the Asian side of the suture, not along the proto-Himalayan belt. At the end of this period, a small part of the subducted Indian continental margin was exhumed at the base of the Indian crust. Subduction of the Indian plate probably ended by slab breakoff. It was followed by initial Himalayan-wedge thickening by underthrusting of continental units and emplacement of thin-skinned thrustsheets. 
[41] From 50-45 Ma to 25-20 Ma, the underthrusting of the HHC led to the thickening and warming of the Himalayan orogenic wedge, as reflected by the Eo-Himalayan metamorphism. Plate velocity decreased progressively down to 5-6 $\mathrm{cm} \cdot \mathrm{yr}^{-1}$ since $45 \mathrm{Ma}$, and was stabilized thereafter, indicating that kinematics equilibrium was progressively reached. At the surface, this period corresponds to a very long stage of negligible sediment accumulation, suggesting virtually no foreland basin subsidence. Low erosion rates at this stage can be related either to a lack of significant relief in the proto-Himalayan belt related to a low-angle continental subduction plane and/or to arid climates at subtropical latitudes before the onset of the monsoon system.

[42] Since 25-20 Ma, the HHC wedge was exhumed along the MCT and the STDS, and alluvial clastic sediments were deposited in the thick foreland basin. The orogenic wedge rapidly grew in both width, as documented by southward propagation of the thrust front until the monsoonal system, profoundly altering athmospheric circulation patterns and earth's climates, was established and strengthened between ca 11 and $6 \mathrm{Ma}$ [Quade et al., 1995].

\section{Acknowledgments}

[45] This work was first presented at the 15th Himalaya- Karakorum -Tibet workshop in Chengdu, China (2000) and benefited from fruitfull discussions with P. Clift, L. Krejzlikova, M. Mattauer, P. Matte, Y. Najman, A. Pêcher, M.P. Searle, P. Tapponnier, P. Treloar, and N. White. We thank P. DeCelles, P. Koons and J. Beavan for critical reviews that helped us to substantially improve this paper. Financial support so SG by INSU-CNRS "Intérieur de la Terre" program and to EG by Cofin MIUR 2001 to P.C.Pertusati.

\section{References}


Achache, J., V. Courtillot, and Y.X. Zhou, Paleaogeographic and tectonic evolution of Southern Tibet since Middle Cretaceous times : New paleomagnetic data and synthesis., J. Geophys. Res., 89, 10311-10339, 1984.

Acton, G.D., Apparent polar wander of India since the Cretaceous with implications for regional tectonics and true polar wander, Mem. Geol. Soc. India, 44, 129-175, 1999.

Aitchison, J.C., Badengzhu, A.M. Davis, J. Liu, H. Luo, J.G. Malpas, I.R.C. McDermid, H. Wu, S.V. Ziabrev, and M. Zhou, Remnants of a Cretaceous intra-oceanic subduction system within the Yarlung-Zangbo suture (southern Tibet), Earth Planet. Sci. Lett., 183, 231-244, 2000.

Allemann, F., Time of emplacement of the Zhob Valley Ophiolites and Bela Ophiolites, Baluchistan (preliminary report), 215-242, 1979.

Baud, A., E. Garzanti, and G. Mascle, Latest marine sediments (Early Paleogene), geological events and nappe structure in central Zanskar area (NW Himalaya), I Himalayan Workshop, Leicester, England., 1985.

Beck, R.A., D.W. Burbank, W.J. Sercombe, A.M. Khan, and R.D. Lawrence, Late Cretaceous ophiolite obduction and Paleocene India-Asia collision in the westernmost Himalaya, Geodinamica Acta, 9, 114-144, 1996.

Berggren, W.A., D.V. Kent, C.C. Swisher, and M.-P. Aubry, A revised Cenozoic geochronology and chronostratigraphy, In Geochronology, time scales and global stratigraphic, edited by Berggren W.A., Kent D.V., Aubry M.-P. and Hardenbol J., 54, 129-212, 1995.

Besse, J., and V. Courtillot, Paleomagnetic maps of the continents bordering the Indian Ocean since the Early Jurassic, J. Geophys. Res., 93, 11791-11808, 1988.

Besse, J., V. Courtillot, J.P. Pozzi, M. Westphal, and Y.X. Zhou, Paleomagnetic estimates of crustal shortening in the Himalayan thrusts and Zangbo suture, Nature, 311, 621-626, 1984. 
Bilham, R., K. Larson, and J. Freymueller, GPS measurements of present-day convergence across the Nepal Himalaya, Nature, 386, 61-64, 1997.

Bossart, P., and R. Ottiger, Rocks of the Murree Formation in northern Pakistan: indicators of descending foreland basin of late Paleocene to middle Eocene age, Eclo. Geol. Helv., 82, 133-165, 1989.

Burbank, D.W., R.A. Beck, and T. Mulder, The Himalayan foreland basin, In The tectonic Evolution of Asia: Cambridge Univ. Press, edited by Yin, A and Harrison, T.M., 149$188,1996$.

Chamberlain, C.P., P.K. Zeitler, and E. Erickson, Constraints on the tectonic evolution of the northwestern Himalaya from geochronologic and petrologic studies of Babusar Pass, Pakistan., J. Geol., 99, 829-849, 1991.

Chawla, H.S., D. Marquer, J.D. Kramers, I.M. Villa, and F. Bussy, Petrology and age of the Kinnar Kailas granite: evidence for an ordovician post-orogenic extension in the Higher Himalayan Crystalline, Sutlej, India, Earth Sci. Front., 7, 50-51, 2000.

Chemenda, A.I., J.P. Burg, and M. Mattauer, Evolutionary model of the Himalaya-Tibet system: geopoem based on new modelling, geological and geophysical data, Earth Planet. Sci. Lett., 174, 397-409, 2000.

Clift, P.D., A. Carter, M. Krol, and E. Kirby, Constraints on India-Eurasia Collision in the Arabian Sea Region taken from the Indus Group, Ladakh Himalaya, India.,edited by Clift, P.D., Kroon, D., Craig, J., and Gaedicke, C., 195, 2002.

Clift, P.D., P.J. Degnan, R. Hannigan, and J. Blusztajn, Sedimentary and geochemical evolution of the Dras forearc basin, Indus Suture, Ladakh Himalaya, India, Geol. Soc. Am. Bull., 112, 450-466, 2000.

Corfield, R.I., M. Searle, and R.G. Owen, Photang thrustsheet: an accretionary complex structurally below the Spontang ophiolite constraining timing and tectonic environment of ophiolite obduction, ladakh, Himalaya, Geol. Soc. London, 156, 1031-1044, 1999. 
Courtillot, V., J. Besse, D. Vandamme, R. Montigny, J.J. Jaeger, and H. Capetta, Deccan flood basalts at the Cretaceaous/Tertiary boundary?, Earth Planet. Sci. Lett, 80, 361374, 1986.

Critelli, S., and E. Garzanti, Provenance of the Lower Tertiary Murree redbeds (HazaraKashmir syntaxis, Pakistan) and initial rising of the Himalayas, Sedim. Geology, 89, 265-284, 1994.

Dalziel, I.W.D., B.C. Storey, S.W. Garett, A.M. Grunow, L.D.B. Herrod, and R.J. Pankhurst, Extensional tectonics and fragmentation of Gondwaland, in Continental Extensional Tectonics, edited by M.P. Coward, J.F. Dewey and P.L. Hancock, Geol. Soc. London Spe. Pub., 28, 443-441, 1987.

DeCelles, P.G., and P.C. DeCelles, Rate of shortening, propagation, underthrusting, and felxural wave migration in continental orogenic systems, Geology, 29, 135-138, 2001.

DeCelles, P.G., G.E. Gehrels, J. Quade, and T.P. Ojha, Eocene-early Miocene foreland basin development and the history of Himalayan thrusting, western and central Nepal, Tectonics, 17, 741-765., 1998.

DeCelles, P.G., D.M. Robinson, J. Quade, T.P. Ojha, C.N. Garzione, P. Copeland, and B.N. Upreti, Stratigraphy, structure, and tectonic evolution of the Himalayan fold-thrust belt in western Nepal, Tectonics, 20, 487-509, 2001.

DeCelles, P.G., D.M. Robinson, and G. Zandt, Implications of shortening in the Himalayan fold-thrust belt for uplift of the Tibetan Plateau, Tectonics, 22, XXXX, doi:10.1029/2001TC001322, 2002.

Debon, F., P. Le Fort, S.M.F. Sheppard, and J. Sonet, The four plutonic belt of the Transhimalaya-Himalaya: a chemical, mineralogical, isotopic and chronological synthesis along a Tibet-Nepal section, J. Petrol., 27, 219-250, 1986.

De Mets, C., R.G. Gordon, D.F. Argus, and S. Stein, Current plate motions, Geophys. J. Int., 101, 425-478, 1990. 
Dercourt, J., L.E. Ricou, and B.E. Vrielynck, Atlas tethys, palaeoenvironmental maps, Gauthier-Villars, Paris, 307, 1993.

de Sigoyer, J., V. Chavagnac, J. Blichert-Toft, I.M. Villa, B. Luais, S. Guillot, M. Cosca, and G. Mascle, Dating the Indian continental subduction and collisional thickening in the northwest Himalaya: multichronology of the Tso Morari eclogites, Geology, 28, 487-490, 2000.

de Sigoyer, J., S. Guillot, J.M. Lardeaux, and G. Mascle, Glaucophane-bearing eclogites in the Tso Morari dome (eastern Ladakh, NW Himalaya), Eur. J. Mineral., 9, 1073-1083, 1997.

Dewey, J.F., S. Cande, and W.C. Pitman, Tectonic evolution of the India-Eurasia collision zone, Eclo. Geol. Helv., 82, 717-734, 1989.

England, P.C., and A.B. Thompson, Pressure-Temperature-Time paths of regional metamorphism I. Heat transfer during the evolution of regions of thickened continental crust., J. Petrol., 25, 894-928, 1984.

Foster, G.L., D. Vance, T.W. Argles, and N. Harris, The Tertiary collision-related thermal history of the NW Himalaya, J. Metam. Geol., 20, 827-843, 2002.

Fuchs, G., The geology of Southern Zanskar (Ladakh) - Evidence for the autochtony of the Tethys Zone of the Himalaya, Jb. Geology Bundesanst., 130 (4), 465-491, 1987.

Gaetani, M., and E. Garzanti, Multicyclic history of the Northern India continental margin (Nothwestern Himalaya), AAPG Bull, 75, 1427-1446, 1991.

Garzanti, E., Sedimentary evolution and drowning of a passive margin shelf (Giumal Group; Zanskar Tethys Himalaya, India): palaeoenvironmental changes during final break-up of Gondwanaland, in Himalayan tectonics, edited by Treloar P.J. and Searle M.P., Geol. Soc. London Spe. Pub., 74, 277-298, 1993.

Garzanti, E., Stratigraphy and sedimentary history of the Nepal Tethys Himalayan passive margin, in Advances on the Geology of the Himalaya - Focus on Nepal, edited by Upreti B. and Le Fort P., J. Asian Earth Sci., 17, 805-827, 1999. 
Garzanti, E., A. Baud, and G. Mascle, Sedimentary record of the northward flight of India and its collision with Eurasia (Ladakh Himalaya, India), Geodinamica Acta, 1, 297-312, 1987.

Garzanti, E., and G. Brignoli, Low temperature metamorphism in the Zanskar sedimentary nappes (NW Himalaya, India)., Eclo. Geol. Helv., 82/2, 669-684., 1989.

Garzanti, E., S. Critelli, and R.V. Ingersoll, Paleogeographic and paleotectonic evolution of the Himalayan Range as reflected by detrital modes of Tertiary sandstones and modern sands (Indus transect, India and Pakistan), Geol. Soc. Am. Bull., 108, 631-642, 1996.

Garzanti, E., and H.T. Van, The Indus clastics : forearc basin sedimentation in the Ladakh Himalaya (India)., Sedimentary Geology, 59, 237-249, 1988.

Gnos, E., A. Immenhauser, and T. Peters, Late Cretaceous/early Tertiary convergence between the Indian and Arabian plates recorded in ophiolites and related sediments, Tectonophysics, 271 (1-2), 1-19, 1997.

Grujic, D., M. Casey, M. Davidson, L.S. Hollister, R. Kündig, T. Pavlis, and S. Schmid, Ductile extrusion of the Higher Himalayan Crystalline in Bhutan, Tectonophysics, 260, 21-43, 1996.

Guillot, S., and P. Allemand, 2D thermal modelling of the early evolution of the Himalayan belt, J. Geodym, 34, 77-98, 2002.

Guillot, S., M. Cosca, P. Allemand, and P. Le Fort, Contrasting metamorphic and geochronologic evolution along the Himalayan Belt, in Himalaya and Tibet; mountain roots to mountain tops, edited by A. Macfarlane, R.B. Sorkhabi, and J. Quade, Geol. Soc. Am. Spe. Paper, 328, 117-128, 1999.

Guillot, S., J. de Sigoyer, J.M. Lardeaux, and G. Mascle, Eclogitic metasediments from the Tso Morari area (Ladakh, Himalaya): evidence for continental subduction during IndiaAsia convergence, Contrib. Mineral. Petrol., 128, 197-212, 1997. 
Guillot, S., K. Hattori, and J. Sigoyer de, Mantle wedge serpentinization and exhumation of eclogites: insights from eastern Ladakh, northwest Himalaya, Geology, 28, 199-202, 2000.

Guillot, S., K.V. Hodges, P. Le Fort, and A. Pêcher, New constraints on the age of the Manaslu leucogranite : evidence for episodic tectonic denudation in the Central Himalayas, Geology, 22, 559-562, 1994.

Halim, N., J.P. Cogné, Y. Chen, R. Atasiei, J. Besses, J. Courtillot, S. Gilder, J. Marcoux, and R.L. Zhao, New Cretaceous and Early tertiary paleomagnetism results from Xining-Langzhou basin, Kunlun and Quiantang blocks, China: implications on the geodynamic evolution of Asia, J. Geophys. Res., 103, 21,025-21045, 1998.

Harrison, M.T., M. Grove, O.M. Lovera, and E.J. Catlos, A model for the origin of Himalayan anatexis and inverted metamorphism, J. Geophys. Res., 103, 27017-27032, 1998.

Herren, E., Zanskar shear zone : northeast-southwest extension within the Higher Himalayas (Ladakh, India)., Geology, 15, 409-413, 1987.

Hodges, K.V., J.W.e. Geissman, and A.F.E. Glazner, Tectonics of the Himalaya and southern Tibet from two perspectives. Special focus on the Himalaya, Geol. Soc. Am. Bull., 112, 324-350, 2000.

Hodges, K.V., R.R. Parrish, and M.P. Searle, Tectonic evolution of the central Annapurna Range, Nepalese Himalayas, Tectonics, 15, 1264-1291, 1996.

Hubbard, M.S., and T.M. Harrison, 40Ar/39Ar age constraints on deformation and metamorphism in the Main Central Thrust zone and Tibetan Slab, Eastern Nepal Himalaya, Tectonics, 8, 865-880, 1989.

Jaeger, J.J., V. Courtillot, and P. Tapponnier, Paelontological view of the ages of the Deccan Traps, the Cretaceous/tertiary boundary, and the India/Asia collision, Geology, 17, 316-319, 1989. 
Kelemen, P.B., I. Reuber, and G. Fuchs, Structural evolution and sequence of thrusting in the High Himalayan, Tibetan-Tethys and Indus suture zones of Zanskar and Ladakh, Western Himalaya: Discussion, J. Struct. Geol., 10, 129-132, 1988.

Kelemen, P.B., and M.D. Sonnenfeld, Stratigraphy, structure, petrology and local tectonics, central Ladakh, NW Himalaya, Schweiz. Mineral. Petrogr. Mitt, 63, 267-287, 1983.

Klootwijk, C., M.L. Sharma, and T.B. Gergan J., Shah S.K. and Agarwal V., The extent of greater India, II. Palaeomagnetic data from the Ladakh intrusives in Kargil, Northwestern Himalayas., Earth Planet. Sci. Lett., 44, 47-64, 1979.

Klootwijk, C.T., J.S. Gee, J.W. Peirce, G.M. Smith, and P.L. McFadden, An early IndiaAsia contact: paleomagnetic constraints from Ninetyeast Ridge, ODP Leg 121, Geology, 20, 395-398, 1992.

Lacassin, R., H. Maluski, P.H. Leloup, P. Tapponnier, C. Hinthong, K. Siribahakdi, S. Chuarivoj, and A. Charoenravat, Tertiary diachronism erxtrusion and deformation of wetern Indochina: structural and 40Ar/39Ar evidence from NW Thailand, J. Geophys. Res., 102, 10,013-10,037, 1997.

Lal, N., and K.K. Nagpaul, Fission track geochronology of some Himalayan rocks, Himal. Geol., 5, 104-114, 1975.

Le Fort, P., The Himalayan orogenic segment., In Tectonic evolution of the Tethyan region, edited by A.M.C. Sengör, Kluwer Academic Press, 259, 289-386, 1989.

Le Fort, P., S. Guillot, and A. Pêcher, HP metamorphic belt along the Indus suture zone of NW Himalaya : new discoveries and significance, C. R. Acad. Sci., Paris, 325, 773-778, 1997.

Le Pichon, X., M. Fournier, and L. Jolivet, Kinematics, topography and extrusion in the India-Eurasia collision, Tectonics, 11, 1085-1098, 1992.

Mahéo, G., H. Bertrand, S. Guillot, G. Mascle, A. Pêcher, C. Picard, and J. de Sigoyer, Témoins d un arc immature téthysien dans les ophiolites du Sud Ladakh (NW Himalaya, Inde), C. R. Acad. Sci., Paris, 330, 289-295, 2000. 
Mahéo, G., S. Guillot, B.-T. Y., Y. Rolland, and A. Pêcher, A slab breakoff model for the Neogene thermal evolution of South Karakorum and South Tibet, Earth and Planetary Sciences Letters, 195, 45-58, 2002.

Matte, P., Mattauer;M., J.M. Jolivet, and D.A. Griot, Continental subductions beneath Tibet and the Himalayan orogeny : a review, Terra Nova, 9, 264-270, 1997.

Molnar, P., F. Pardo-Casas, and J. Stock, The Cenozoic and Late Cretaceous evolution of the Indian Ocean Basin: uncertainties in the reconstructed positions of the Indian, African and Antarctic plates, Basin Res., 1, 23-40, 1988.

Molnar, P., and P. Tapponnier, Cenozoic tectonics of Asia: effects of a continental collision, Science, 189, 419-426, 1975.

Montgomery, D.R., G. Balco, and S.D. Willett, Climate, tectonics, and the morphology of the Andes, Geology, 29, 449-452, 2001.

Najman, Y., and E. Garzanti, An integrated approach to provenance studies: reconstructing early Himalayan palaeogeography and tectonic evolution from Tertiary foredeep sediments, N. India, Geol. Soc. Am. Bull., 112, 435-449, 2000.

Najman, Y.M.R., M.S. Pringle and L. Godin,, Ar-Ar dating of the oldest Himalayan sediments indicates erosion >15 My later than previously believed, Nature, 410, 194$197,2001$.

Najman, Y.M.R., M.S. Pringle, M.R.W. Johnson, A.H.F. Robertson, and J.R. Wijbrans, Laser 40Ar/39Ar dating of single detrital muscovite grains from early foreland basin sediments in India: implications for early Himalayan evolution, Geology, 25, 535-538, 1997.

Nelson, K.D., W. Zhao, L.D. Brown, J. Kuo, J. Che, X. Liu, S.L. Klempere, Y. Makovsky, R. Meissner, J. Mechie, R. Kind, F. Wenzel, J. Ni, J. Nabelek, C. Leshou, H. Tan, W. Wei, A.G. Jones, J. Booker, M. Unsworth, W.S.F. Kidd, M. Hauck, D. Alsdorf, A. Ross, M. Cogan, C. Wu, E. Sandvol, and M. Edwards, 
Partially Molten Middle Crust Beneath SoutherTibet: Synthesis of Project INDEPTH Results., Science, 274, 1684-1696, 1996.

Ni, J., and M. Barazangi, Seismotectonics of the Himalayan collision zone: geometry of the underthrusting Indian plate beneath the Himalaya, J. Geophys. Res., 89, 1147-1163, 1984.

Nicora, A., E. Garzanti, and E. Fois, Evolution of the Tethys Himalaya continental shelf during Maastrichtian to Paleocene (Zanskar, India), Riv. It. Paleont. Strat., 92, 439-496, 1987.

Norton, I.O., and J.G. Sclater, A model for the evolution of the Indian Ocean and the breakup of Gondwanaland, J. Geophys. Res, 84, 6803-6830, 1979.

O'Brien, P., N. Zotov, R. Law, KhanA.M., and M.Q. Jan, Coesite in Himalayan eclogite and implication for models of India-Asia collision, Geology, 29, 435-438, 2001.

Patriat, P., and J. Achache, India-Eurasia collision chronology has implications for crustal shortening and driving mechanisms of plates, Nature, 311, 615-621, 1984.

Patzelt, A., H. Li, J. Wang, and E. Appel, Pleomagnetism of Cretaceous to Tertiary sediments from southern Tibet: Evidence for the extent of the northern margin of India prior to the collision with Eurasia, Tectonophysics, 259, 259-284, 1996.

Pêcher, A., and P. Le Fort, Late Miocene tectonic evolution of the Karakorum-Nanga Parbat contact zone (Pakistan), in Himalaya and Tibet; mountain roots to mountain tops, edited by A. Macfarlane, R.B. Sorkhabi, and J. Quade, Geol. Soc. Am. Spe. Paper, 328, 145$158,1999$.

Pedersen, R.B., M.P. Searle, and R.I. Corfield, U-Pb zircon ages from the Spontang Ophiolite, Ladakh Himalaya, J. Geol. Soc. London, 158, 513-520, 2001.

Pivnik, D.A., and N.A. Wells, The transition from Tethys to the Himalaya as recorded in northwest Pakistan, Geol. Soc. Am. Bull, 108, 1295-1313, 1996.

Pognante, U., P. Benna, and P. Le Fort, High-pressure metamorphism in the High Himalayan Crystallines of the Stak valley, northeastern Nanga-Parbat-Haramosh 
syntaxis, Pakistan Himalaya., in Himalayan Tectonic, edited by Treloar, P.J. and Searle, M.P., Geol. Soc. London Spe. Pub., 74, 161-172, 1993.

Pognante, U., and D.A. Spencer, First record of eclogites from the High Himalayan belt, Kaghan valley (northern Pakistan), European Journal of Mineralogy, 3/3, 613-618, 1991.

Powell, C.M., S.R. Roots, and J.J. Veevers, Pre-breakup continental extension in East Gondwanaland and the early opening of the eastern Indian Ocean., Tectonophysics, 155 , 261-283, 1988.

Premoli Silva, I., E. Garzanti, and M. Gaetani, Stratigraphy of the Chikkim and Fatu La Formations in the Zangla and Zumlung Units (Zanskar Range, India) with comparisons to the Thakkhola region (central Nepal): Mid-Cretaceous evolution of the Indian passive margin, Riv. It. Paleont. Strat, 97, 511-564, 1991.

Prince, C., G. Foster, D. Vance, N. Harris, and J. Baker, The thermochronology of the High Himalayan Crystalline in the Garhwal Himalaya : prograde history of a polymetamorphic slab, Terra Nostra, 99/2, 119-120, 1999.

Qayyum, M., A.R. Niem, and R.D. Lawrence, Detrital modes and provenance of the Paleogene Khojak Formation in Pakistan: implications on early Himalayan orogeny and unroofing, Geol. Soc. Am. Bull., 24, 835-838, 2001.

Quade, J., and T.E. Cerling, Expansion of C-4 grasses in the Late Miocene of Northern Pakistan: Evidence from stable isotopes in paleosols, Palaeogeogr. Palaeoclim., 115 (14), 91-116, 1995.

Quayyum, M., R.D. Lawrence, and A.R. Niem, Discovery of the paleo-Indus delta fan complex, J. Geol. Soc. London, 154, 753-756, 1997.

Replumaz, A., and P. Tapponnier, Reconstruction of the deformed zone between Indian and Asia by backward motion of lithospheric blocks, J Geophys. Res, in press, 2003. 
Reuber, I., M. Colchen, and C. Mevel, The geodynamic evolution of the South-Tethyan margin in Zanskar, NW Himalaya, as revealed by the Spontang ophiolitic melange, Geodinamica Acta, 1, 283-296, 1987.

Robertson, A.H.F., M.A.e. Khan, P.J., Formation of melanges in the Indus suture zone, Ladakh Himalaya by successive subduction-related, collisional and post-collisional processes during late Mesozoic-late Tertiary time, in Tectonics of the Nanga Parbat syntaxis and the western Himalaya, edited by Treloar, P. Searle, M.P. and Jan M.Q., Geol. Soc. Spec. Pub., 170, 333-374, 2000.

Robinson, D.M., D. P.G., P.J. Patchett, and C.N. Garzione, The kinematic history of the Nepalese Himalaya interpreted from Nd isotopes, Earth Planet. Sci. Lett., 192, 507-521, 2001.

Rolland, Y., G. Mahéo, S. Guillot, and A. Pêcher, Tectono-metamorphic evolution of the Karakoram Metamorphic complex (Dassu-Askole area, NE Pakistan): mid-crustal granulite exhumation in a compressive context, J. Metam. Geol., 19, 741-762, 2001.

Rowley, D.B., Age of initiation of collision between India and Asia:a review of stratigraphic data, Earth Planet. Sci. Lett., 145, 1-13, 1996.

Searle, M.P., Stratigraphy, structure and evolution of the Tibetan-Tethys zone in Zanskar and the Indus suture zone in the Ladakh Himalaya., Trans. Royal Soc. Edinburgh, 73, 205219, 1983.

Searle, M.P., M. Asif Khan, J.E. Fraser, and S.J. Gough, The tectonic evolution of the Kohistan-Karakoram collision belt along the Karakoram highway transect, north Pakistan, Tectonics, 18, 929-949, 1999.

Searle, M.P., D.J. Waters, D.C. Rex, and R.N. Wilson, Pressure-temperature and time constraints on Himalayan metamorphim from eastern Kasmir and western Zanskar, Geol. Soc. London, 149, 753-773, 1992. 
Searle, M.P., B.F. Windley, M.P. Coward, D.J.W. Cooper, D. Rex, L. Tingdong, X. Xuchang, V.C. Jan, V.C. Thakur, and S. Kumar, The closing of Tethys and the tectonics of the Himalaya, Geol. Soc. Am. Bull., 98, 678-701, 1987.

Smith, H.A., C.P. Chamberlain, and P.K. Zeitler, Timing and duration of himalayan metamorphism within the India plate, northwest Himalaya, Pakistan, J. Geol., 102, 493$508,1994$.

Spencer, D.A., and D. Gebauer, Shrimp evidence for a Permian protolith age and a $44 \mathrm{Ma}$ metamorphic age for the himalayan eclogites (Upper Kaghan, Pakistan): Implications for the subduction of Tethys and the subdivision terminology of the NW Himalaya., 11th H.K.T. Workshop, 147, 1996.

Steck, A., L. Spring, J.C. Vannay, H. Masson, E. Stutz, H. Bucher, R. Marchant, and J.C. Tieche, Geological transect across the northwestern Himalaya in eastern Ladakh and Lahul (a model for the continental collision of India and Asia), Eclo. Geol. Helv, 86, 219-263, 1993.

Stow, D.A.V., K. Amano, P.S. Balson, G.W. Brass, J. Corrigan, C.V. Raman, J.J. Tiercelin, M. Towsend, and N.P. Wijayanda, Sediment facies and process on the distal Bengal fan, Proc. Ocean Drill Progr., Sci. Res., College station, 116, 377-396, 1990.

Tapponnier, P., G. Peltzer, and R. Armijo, On the mechanics of the collision between India and Asia., In Collision tectonics, edited by Coward M.P. and Riess A.C.. Geol. Soc. Spec. Pub., London, 19, 115-157, 1986.

Tapponnier, P., G. Peltzer, Y. Le Dain, R. Armijo, and P. Cobbold, Propagating extrusion tectonics in Asia : new insights from simple experiments with plasticine., Geology, 10, 611-616, 1982.

Tapponnier, P., X. Zhiqin, F. Roger, B. Meyer, N. Arnaud, G. Wittlinger, and Y. Jingsui, Oblique Stepwise Rise and Growth of the Tibet Plateau, Science, 294, 1671$1677,2001$. 
Tonarini, S., I. Villa, M. Oberli, F. Meier, D.A. Spencer, U. Pognante, and J.G. Ramsay, Eocene age of eclogite metamorphism in Pakistan Himalaya : implications for IndiaEurasia collision., Terra Nova, 5, 13-20, 1993.

Treloar, P.J., R.D. Broughton, M.P. Williams, M.P. Coward, and B.F. Windley, Deformation, metamorphism and imbrication of the Indian plate, south of the Main Mantle Thrust, north Pakistan., J. Metam. Geol., 7, 111-126, 1989.

Treloar, P.J., and M.P. Coward, Indian plate motion and shape : constraints on the geometry of the Himalaya orogen, Tectonophysics, 191, 189-198, 1991.

Treloar, P.J., M.G. Petterson, M.Q. Jan, and M. Sullivan, A re-evaluation of the stratigraphy and evolution of the Kohistan arc sequence, Pakistan Himalaya: implications for magmatic and tectonic arc building processes, J. Geol. Soc. London, 153, 681-693, 1996.

Treloar, P.J., and D.C. Rex, Cooling and uplift histories of the crystalline thrust stack of the Indian plate internal zones west of Nanga Parbat, Pakistan Himalaya, Tectonophysics, 180, 323-349, 1990.

Van der Voo, R., W. Spakman, and H. Bijwaard, Tethyan subducted slabs under India, Earth Planet. Sci. Lett., 171, 7-20, 1999.

Vance, D., and E. Mahar, Pressure-temperature paths from P-T pseudosections and zoned garnets: potential, limitations and examples from the Zanskar Himalaya, NW India, Contrib Mineral Petrol, 132, 225-245, 1998.

Vannay, J.C., and B. Grasemann, Inverted metamorphism in the high Himachal Pradesh (NW India): phase equilibria versus thermobarometry, J. Mineral. Petrol., 78, 107-132, 1998.

Weinberg, R.F., and W.J. Dunlap, Growth and deformation of the Ladakh Batholith, Northwest Himalayas; implications for timing of continental collision and origin of calcalkaline batholiths, J. Geol., 108, 303-320, 2000. 
White, N., E. Garzanti, M. Pringle, R. Parrish, G. Nowell, H. Chapman, Y. Najman, M. Bickle, P. Friend, D. Burbank, and A. Maithani, The provenance of the Dharamsala Formation, XV Himalaya - Tibet - Karakorum Workshop, Chengdu (China), 2000.

White, N., M. Pringle, E. Garzanti, M. Bickle, Y. Najman, H. Chapman, and P. Friend, Constraints on the exhumation and erosion of the High Himalayan slab, NW India, from foreland basin deposits, E.P.S.L., 195, 29-44, 2002.

Willems, H., Z. Zhou, B. Zhang, and K.-U. Gräfe, Stratigraphy of the Upper Cretaceous and Lower Tertiary strata in the Tethyan Himalayas of Tibet (Tingri area, China), Geol. Rundsch, 85, 723-754, 1996.

Yoshyuki Kaneko, Hiroshi Yamamoto, Ikuo Katayama, Haffez Rehman, Allah Kausar, and Kazuyuki Shinaishi, Coesite inclusions and prograde compositional zonation of zircons in Himalaya gneisses, NW Himalaya, Pakistan. Evidence from Schrimp - Dating of cosite bearing zircon., UHPM Workshop at Waseda University, 4A03, 121-123, 2001.

Zeitler, P.K., and C.P. Chamberlain, Petrogenetic and tectonic significance of young leucogranites from the Himalaya, Pakistan, Tectonics, 10, 729-741, 1991. 


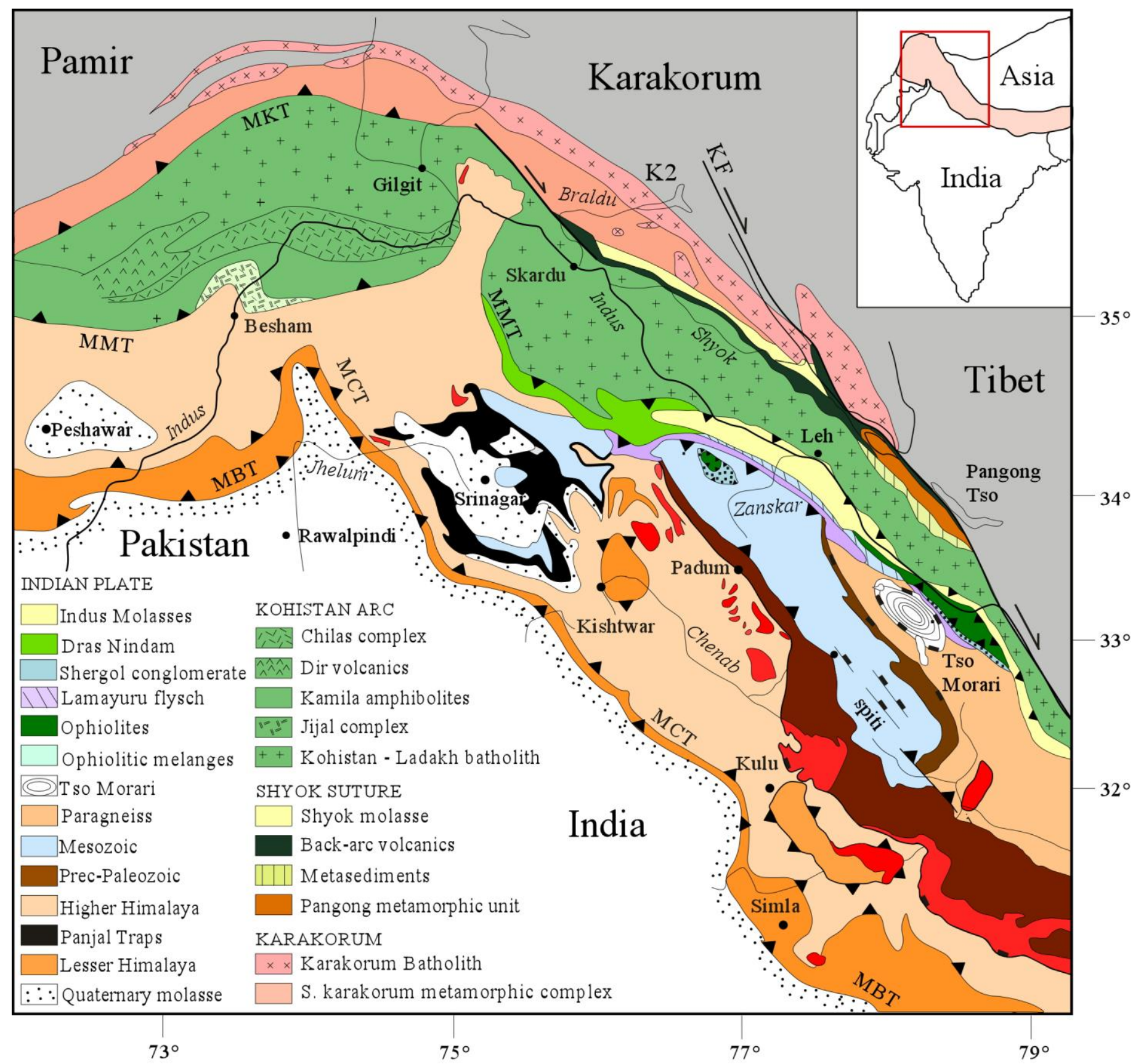

Figure 1 : Geological map of the Northwestern Himalaya with the location of the figure2. [after Chawla et al. 2000, Searle et al., 1999 ; Pêcher and Le Fort, 1999 and Mahéo et al., 2000] 


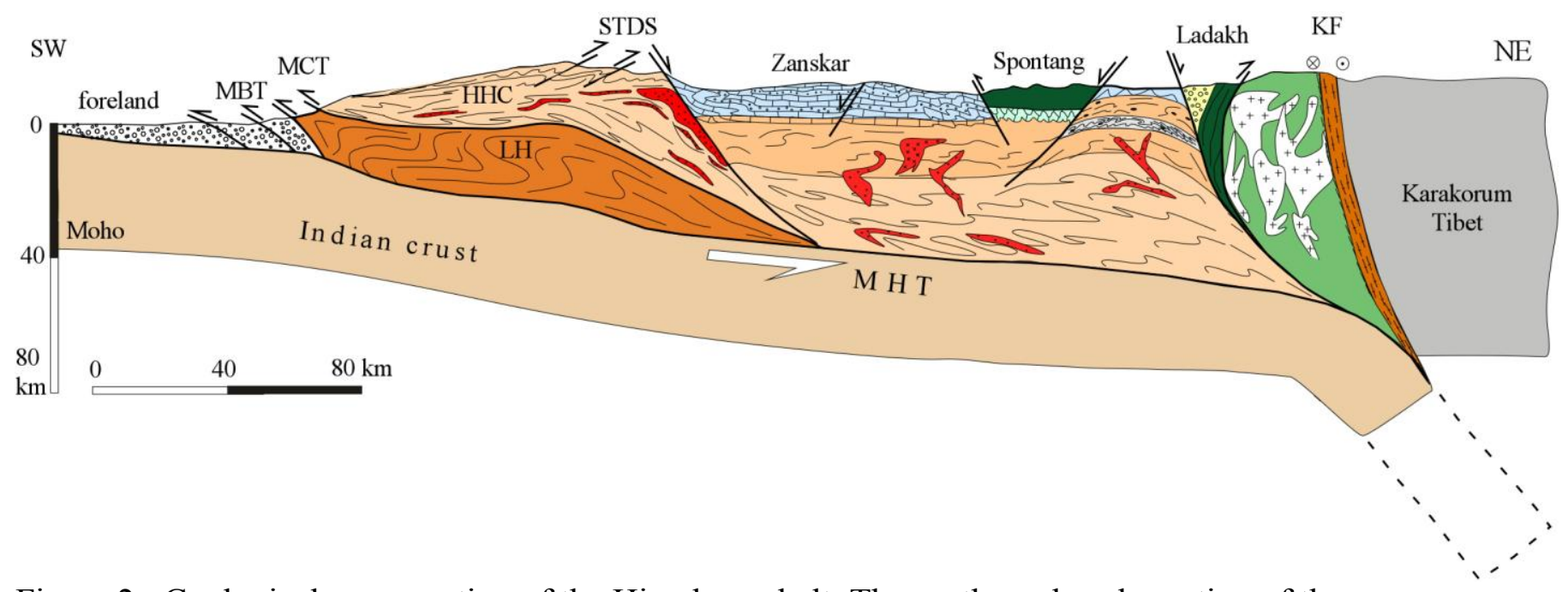

Figure 2 : Geological cross section of the Himalayan belt. The northward prolongation of the MHT is deduced from Ni and Barazangi [1984] and Nelson et al. [1996]

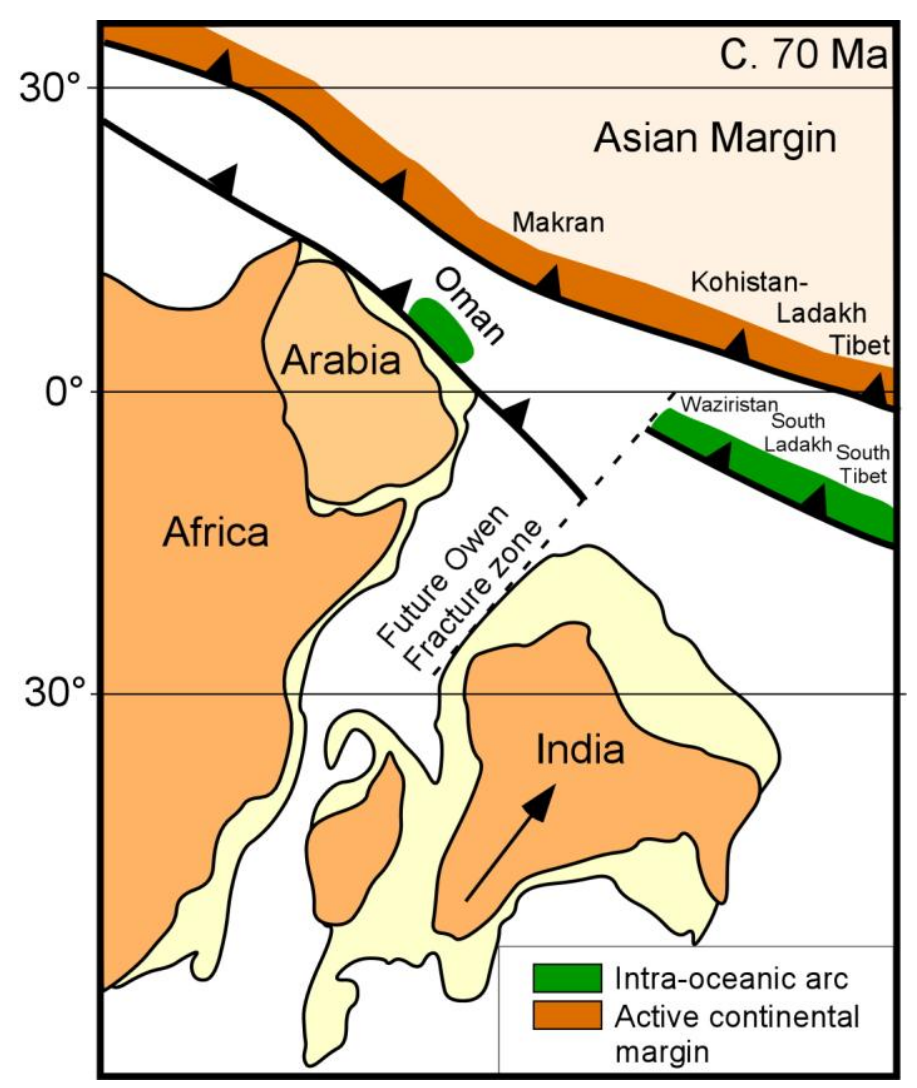

Figure 3: Possible relationships between the Indian plate and the north Tethys subduction during the Upper Cretaceous 


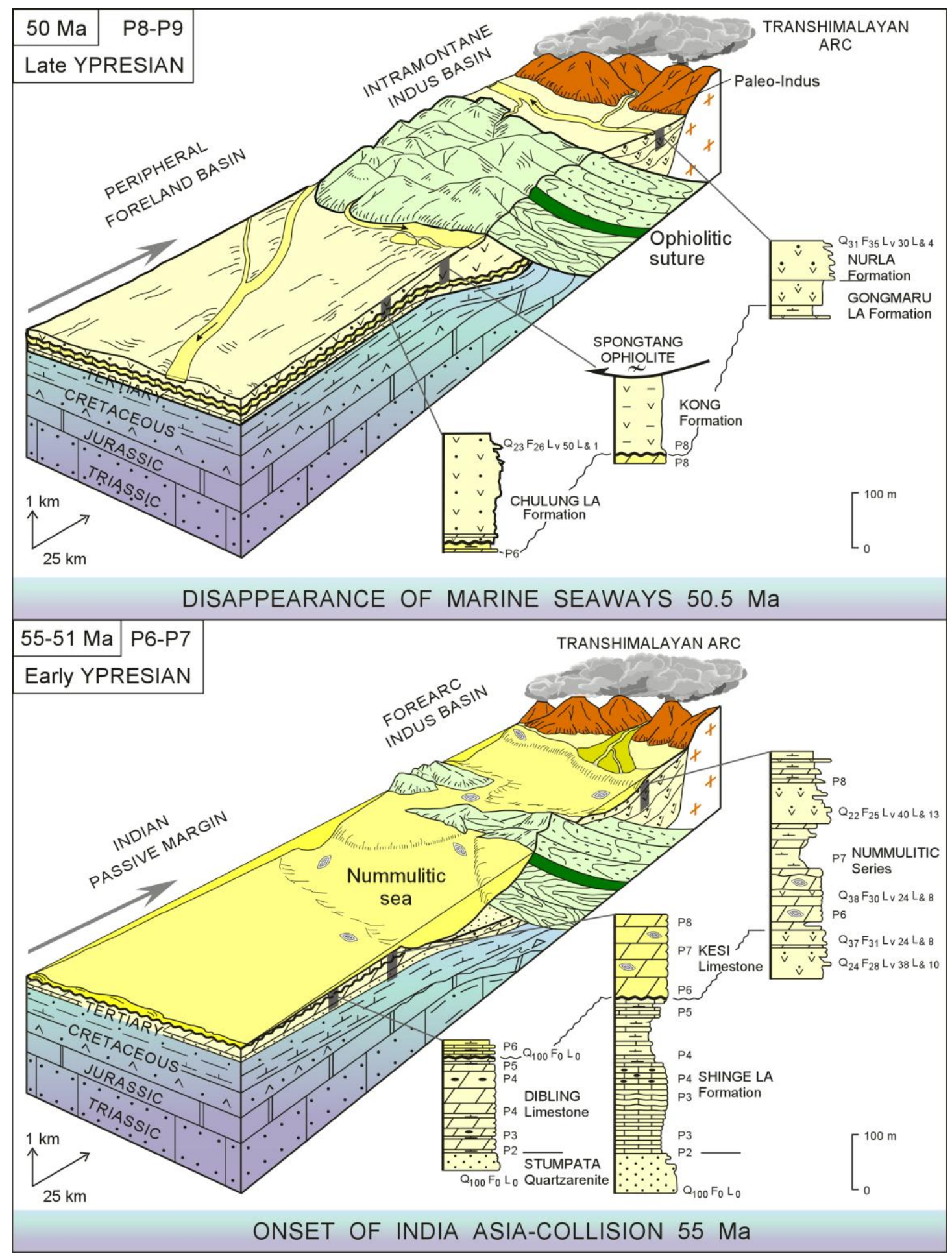

Figure 4: Complete chronology of the India-Asia collision is faithfully recorded in the Paleogene sedimentary record of both Indian passive and Transhimalayan active margins (Garzanti et al., 1987; Garzanti and Van Haver, 1988). After intial continent-continent contact close to the Paleocene-Eocene boundary (55 Ma), the space between colliding continents was filled by shallow Nummulitic seas between 55 and 51 Ma (foraminiferal zones P6-P7; Berggren et al., 1995). At $50.5 \mathrm{Ma}$ (zone P8) marine sedimentation was finally replaced by widespread deposition of continental volcaniclastic redbeds including ophiolitic detritus, which onlapped both the passive-margin succession on the Indian side and the forearc-basin succession on the Asian side. QFL data according to the Gazzi-Dickinson method $(\mathrm{Q}=$ quartz; $\mathrm{F}=$ feldspars; Lv= volcanic grains; Land= other lithic grains; Garzanti et al., 1996). 


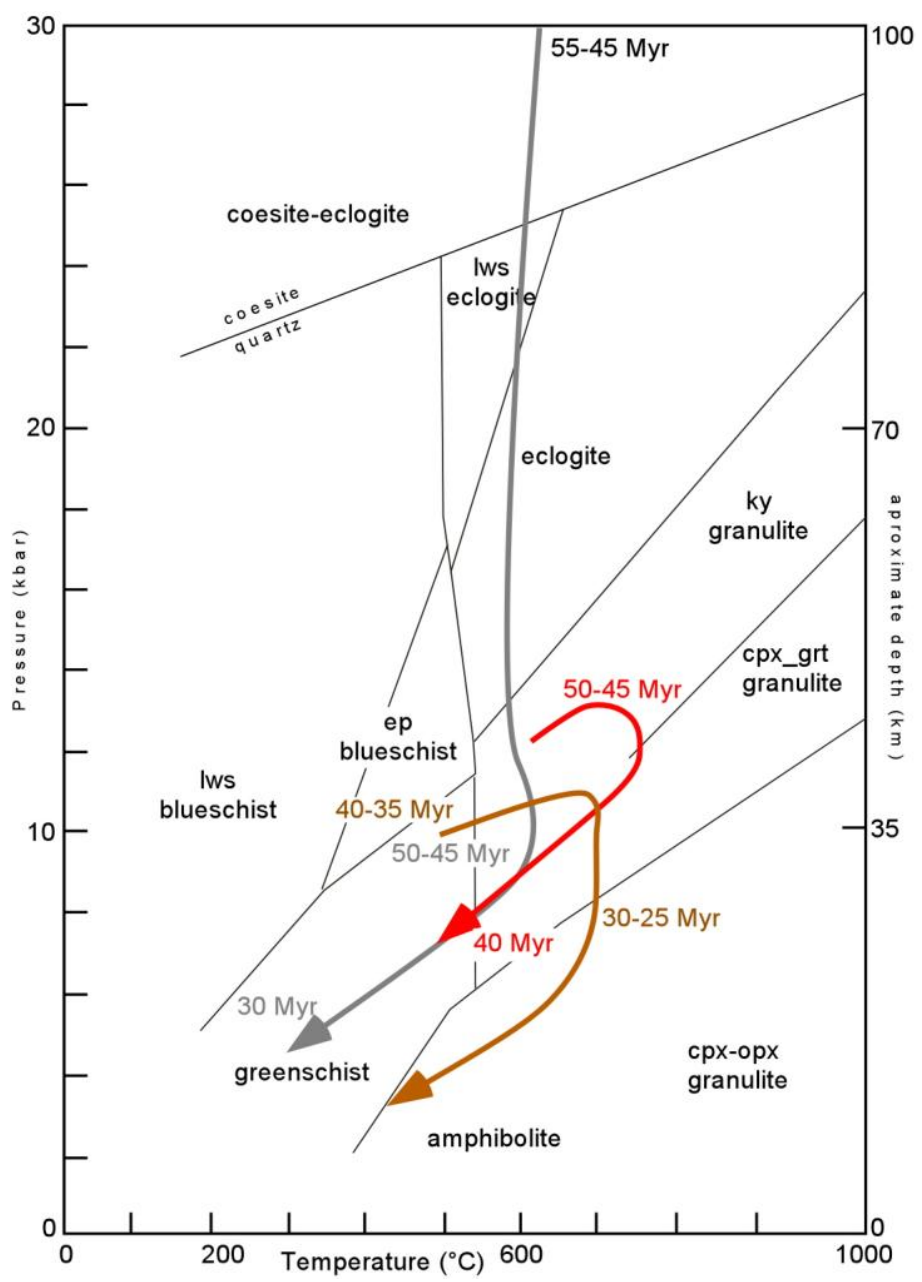

Figure 5: Pressure-Temperature-time (P-T-t) path evolution of the main tectono-metamorphic units in NW Himalaya and South Karakorum. In gray: eclogitic units. In red: the early granulitic unit preserved in NW Pakistan. In brown: the HHC. In orange: the Karakorum metamorphic complex (references in the text). 

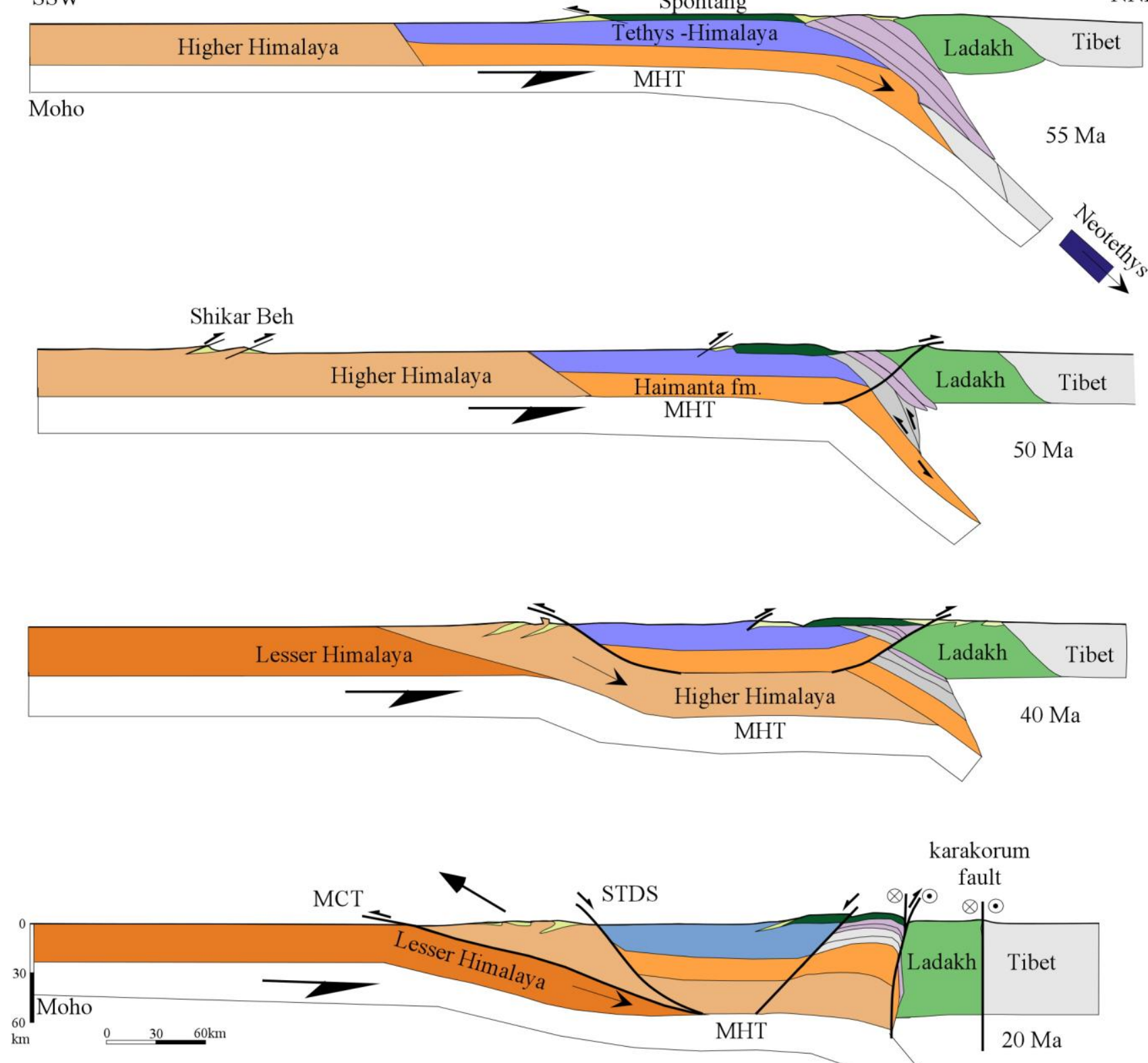

Figure 6 : Balanced cross-sections of the evolution of the Himalayan belt, obtained by retrodeformation of the figure 2. In this reconstruction, we admited that the MHT is active since the onset of the collision. This model does not take into account the internal deformation, evaluated at about $30 \%$ in the ductile crust [Grujic et al., 2000].

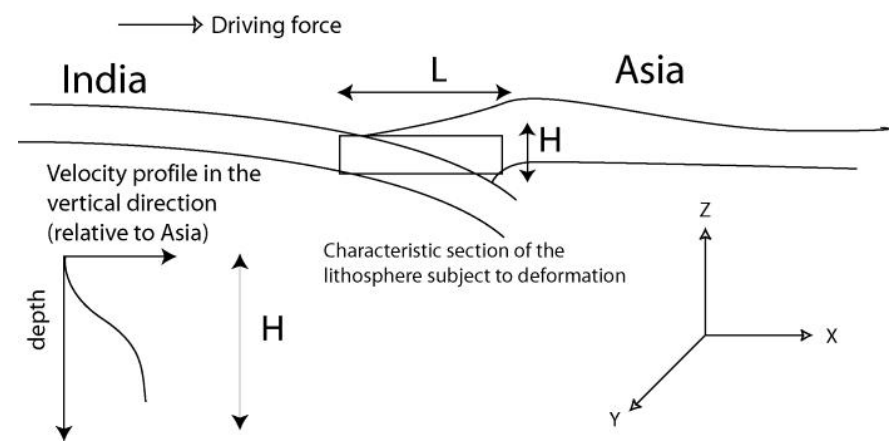

Figure 7: Schematic cross-section of the geometry of the India-Asia collision considered as a zone of two converging block system 


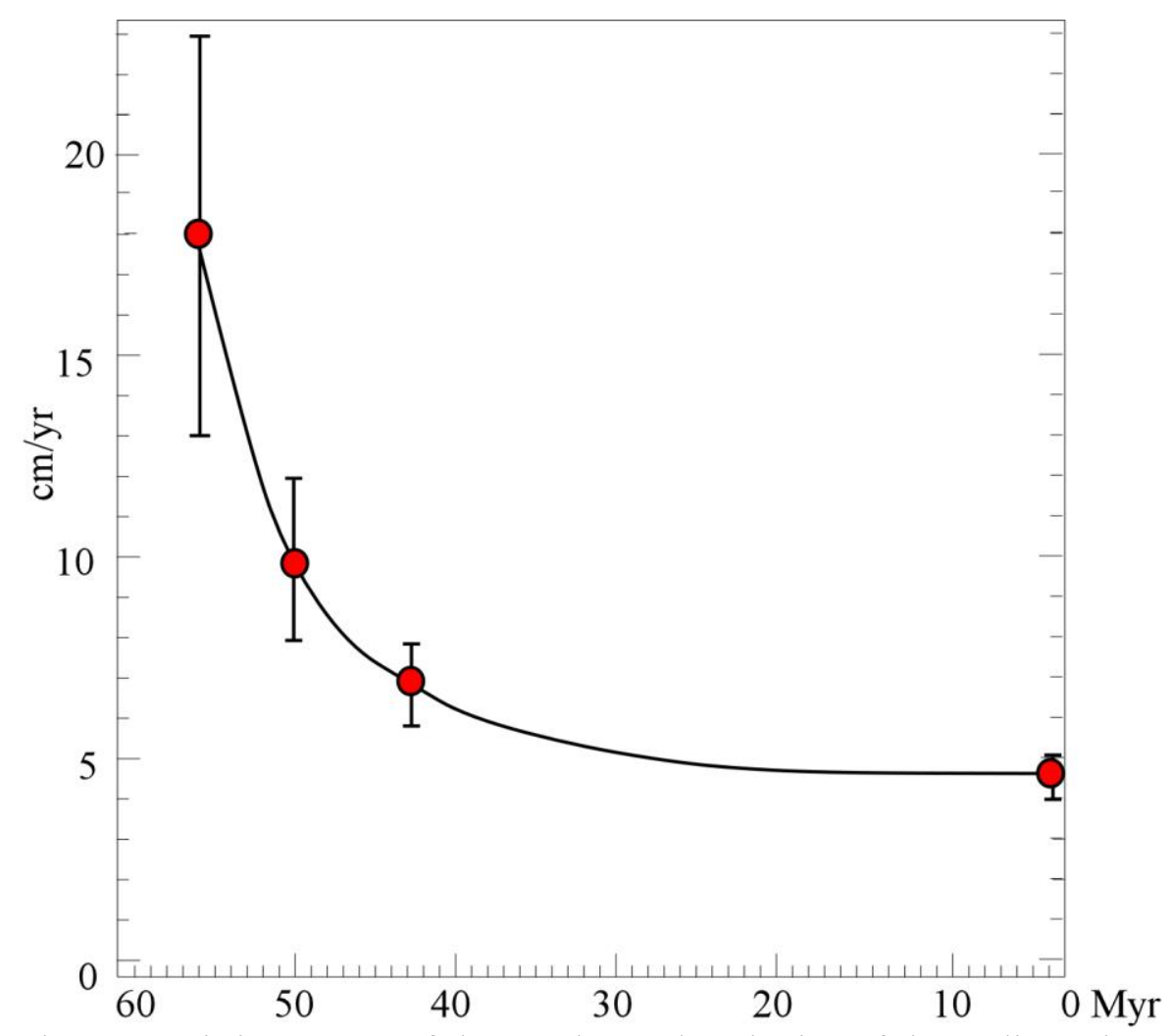

Figure 8: Fitting curve of the north-south velocity of the India-Asia convergence since $55 \mathrm{Ma}$ deduced from the paleomagnetic data (see text for the origin of the data and for the method of fiiting)

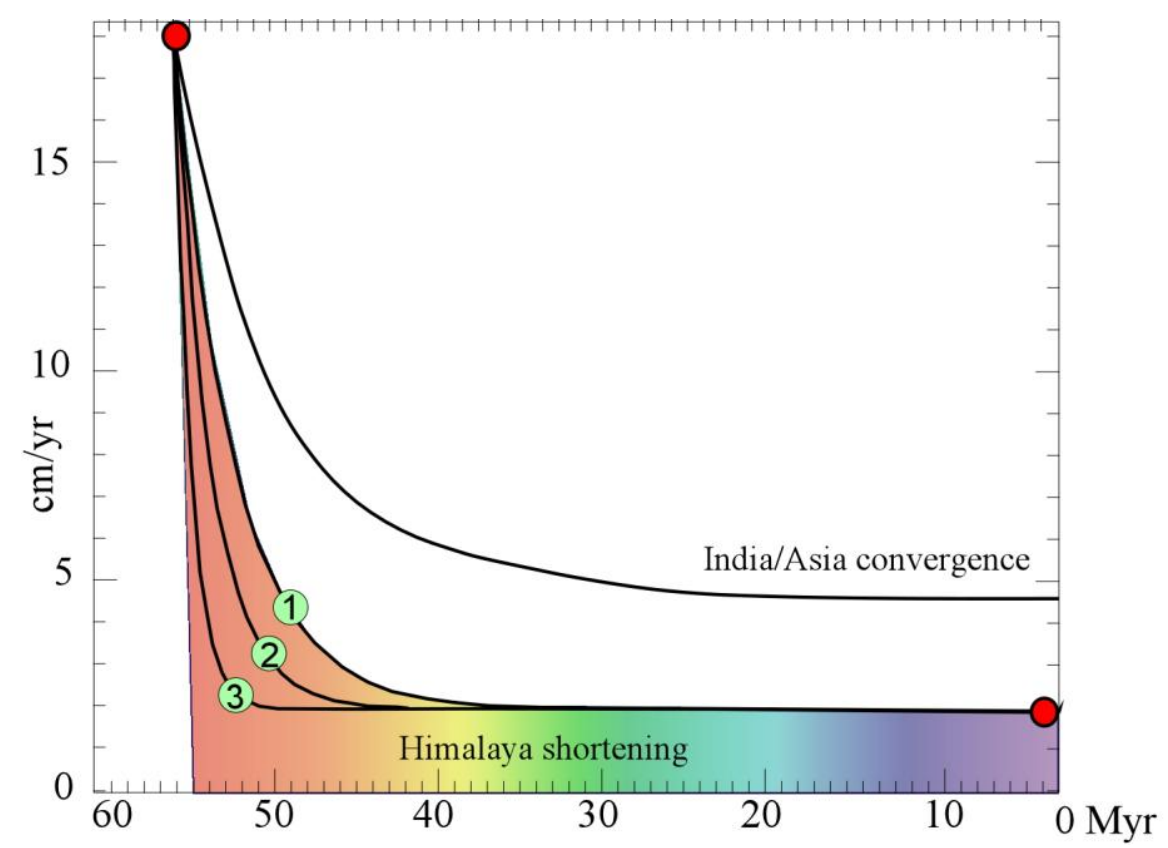

Figure 9: Fitting curves of the Himalayan shortening rate. Curve 1: the Himalayan shortening is fixed to $1600 \mathrm{~km}$. Curve 2: the Himalayan shortening is fixed to $1350 \mathrm{~km}$. Curve 3: the Himalayan shortening is fixed to $1100 \mathrm{~km}$. 


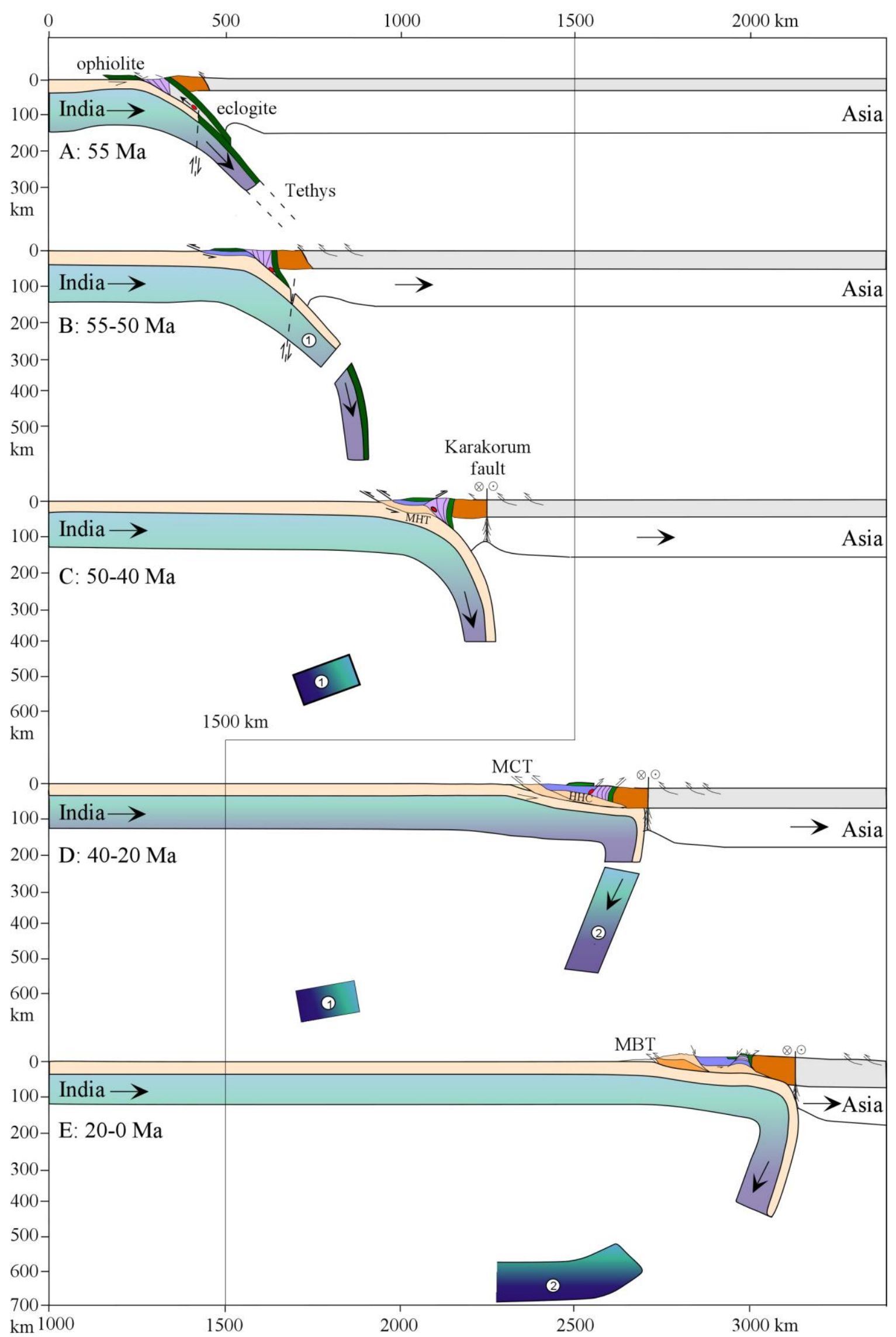

Figure 10: Possible evolution of the NW Himalayan belt at the lithospheric scale. This model takes into account the Tomographic data of Van der Voo et al., [1999], the tectonic evolution and sedimentary discussed in the text and the estimates of Himalayan shortening presented above. 


\begin{tabular}{|l|l|l|l|l|}
\hline & $\mathrm{a}$ & $\mathrm{b}$ & $\mathrm{c}$ & $\mathrm{d}$ \\
\hline Mean & $3.76 \mathrm{~cm} \cdot \mathrm{yr}^{-1}$ & $4.7 \mathrm{Myr}$ & $0.180 \mathrm{Myr}^{-1}$ & $4.5 \mathrm{~cm} \cdot \mathrm{yr}^{-1}$ \\
\hline Fast & $0.99 \mathrm{~cm} \cdot \mathrm{yr}^{-1}$ & $3.8 \mathrm{Myr}$ & $0.178 \mathrm{Myr}^{-1}$ & $5.0 \mathrm{~cm} \cdot \mathrm{yr}^{-1}$ \\
\hline Slow & $5.58 \mathrm{~cm} \cdot \mathrm{yr}^{-1}$ & $5.2 \mathrm{Myr}$ & $0.184 \mathrm{Myr}^{-1}$ & $4.0 \mathrm{~cm} \cdot \mathrm{yr}^{-1}$ \\
\hline
\end{tabular}

Table 1: Computed values of the parameters used to determine the India-Asia convergence and the associated velocity

\begin{tabular}{|l|l|l|}
\hline Period & Total convergence & Rates \\
\hline $55 \mathrm{Ma}->50 \mathrm{Ma}$ & $670 \pm 166 \mathrm{~km}$ & $13.4 \pm 3.3 \mathrm{~cm} \cdot \mathrm{yr}^{-1}$ \\
\hline $50 \mathrm{Ma}->40 \mathrm{Ma}$ & $703 \pm 116 \mathrm{~km}$ & $7.0 \pm 1.2 \mathrm{~cm} \cdot \mathrm{yr}^{-1}$ \\
\hline $40 \mathrm{Ma}->20 \mathrm{Ma}$ & $945 \pm 110 \mathrm{~km}$ & $4.7 \pm 0.6 \mathrm{~cm} \cdot \mathrm{yr}^{-1}$ \\
\hline $20 \mathrm{Ma}->0 \mathrm{Ma}$ & $897 \pm 103 \mathrm{~km}$ & $4.5 \pm 0.5 \mathrm{~cm} \cdot \mathrm{yr}^{-1}$ \\
\hline $55 \mathrm{Ma}->0 \mathrm{Ma}$ & $3215 \pm 496 \mathrm{~km}$ & $5.8 \pm 0.9 \mathrm{~cm} \cdot \mathrm{yr}^{-1}$ \\
\hline $45 \mathrm{Ma}->0 \mathrm{Ma}$ & $2140 \pm 271 \mathrm{~km}$ & $4.7 \pm 0.6 \mathrm{~cm} \cdot \mathrm{yr}^{-1}$ \\
\hline
\end{tabular}

Table 2: North-south India/Asia convergence and associated rates computed with the data of the Table 1

\begin{tabular}{|l|l|l|l|l|}
\hline & a & b & c & d \\
\hline Mean & $0.82 \mathrm{~cm} \cdot \mathrm{yr}^{-1}$ & $5.0 \mathrm{Myr}$ & $0.6 \mathrm{Myr}^{-1}$ & $2.0 \mathrm{~cm} \cdot \mathrm{yr}^{-1}$ \\
\hline
\end{tabular}

Table 3: Estimated parameters used to calculate Himalayan shortening

\begin{tabular}{|l|l|l|}
\hline Period & Convergence & Velocity \\
\hline $55 \mathrm{Ma}->50 \mathrm{Ma}$ & $345 \pm 140 \mathrm{~km}$ & $6.9 \pm 2.9 \mathrm{~cm} \cdot \mathrm{yr}^{-1}$ \\
\hline $50 \mathrm{Ma}->40 \mathrm{Ma}$ & $210 \pm 70 \mathrm{~km}$ & $2.1 \pm 0.7 \mathrm{~cm} \cdot \mathrm{yr}^{-1}$ \\
\hline $40 \mathrm{Ma}->20 \mathrm{Ma}$ & $400 \pm 20 \mathrm{~km}$ & $2.0 \pm 0.1 \mathrm{~cm} \cdot \mathrm{yr}^{-1}$ \\
\hline $20 \mathrm{Ma}->0 \mathrm{Ma}$ & $400 \pm 20 \mathrm{~km}$ & $2.0 \pm 0.1 \mathrm{~cm} \cdot \mathrm{yr}^{-1}$ \\
\hline $55 \mathrm{Ma}->0 \mathrm{Ma}$ & $1355 \pm 250 \mathrm{~km}$ & $2.4 \pm 0.4 \mathrm{~cm} \cdot \mathrm{yr}^{-1}$ \\
\hline
\end{tabular}

Table 4: Himalayan shortening and associated velocities per selected periods

\begin{tabular}{|l|l|l|}
\hline Period & Convergence & Velocity \\
\hline $55 \mathrm{Ma}->50 \mathrm{Ma}$ & $325 \pm 280 \mathrm{~km}$ & $6.5 \pm 5.6 \mathrm{~cm} \cdot \mathrm{yr}^{-1}$ \\
\hline $50 \mathrm{Ma}->40 \mathrm{Ma}$ & $493 \pm 186 \mathrm{~km}$ & $4.9 \pm 1.9 \mathrm{~cm} \cdot \mathrm{yr}^{-1}$ \\
\hline
\end{tabular}




\begin{tabular}{|l|l|l|}
\hline $40 \mathrm{Ma}->20 \mathrm{Ma}$ & $545 \pm 115 \mathrm{~km}$ & $2.7 \pm 0.6 \mathrm{~cm} \cdot \mathrm{yr}^{-1}$ \\
\hline $20 \mathrm{Ma}->0 \mathrm{Ma}$ & $497 \pm 108 \mathrm{~km}$ & $2.5 \pm 0.5 \mathrm{~cm} \cdot \mathrm{yr}^{-1}$ \\
\hline $55 \mathrm{Ma}->0 \mathrm{Ma}$ & $1860 \pm 689 \mathrm{~km}$ & $3.4 \pm 1.25 \mathrm{~cm} \cdot \mathrm{yr}^{-1}$ \\
\hline
\end{tabular}

Table 5: Asian shortening and associated velocity

\begin{tabular}{|c|c|c|c|c|}
\hline Stage & $\begin{array}{l}\text { Oceanic } \\
\text { Subduction }\end{array}$ & $\begin{array}{l}\text { Continental } \\
\text { Subduction }\end{array}$ & $\begin{array}{l}\text { Continental } \\
\text { Collision }\end{array}$ & $\begin{array}{l}\text { Steady-State } \\
\text { Collision }\end{array}$ \\
\hline $\begin{array}{l}\text { Age } \\
\text { Crust type }\end{array}$ & $\begin{array}{l}>55 \mathrm{Ma} \\
\text { oceanic }\end{array}$ & $\begin{array}{l}55-50 \mathrm{Ma} \\
\text { thin Indian crust }\end{array}$ & $\begin{array}{l}50-25 \mathrm{Ma} \\
\text { normal Indian crust }\end{array}$ & $\begin{array}{l}25-0 \mathrm{Ma} \\
\text { normal Indian crust }\end{array}$ \\
\hline India-Asia velocity & $18 \mathrm{~cm} \cdot \mathrm{yr}-1$ & 18 -> 10 cm.yr-1 & $10->4.5 \mathrm{~cm} . \mathrm{yr}-1$ & $4.5 \mathrm{~cm} . \mathrm{yr}-1$ \\
\hline India/Asia convergence & $0 \mathrm{~cm} . \mathrm{yr}-1$ & $670 \pm 166 \mathrm{~km}$ & $1625 \pm 220 \mathrm{~km}$ & $1122 \pm 105 \mathrm{~km}$ \\
\hline Himalayan velocity & 18 cm.yr-1 & $18->2.5$ cm.yr-1 & $2.5->2.0 \mathrm{~cm} . \mathrm{yr}-1$ & $2.0 \mathrm{~cm} . \mathrm{yr}-1$ \\
\hline Himalayan shortening & $0 \mathrm{~km}$ & $345 \mathrm{~km}$ & $510 \pm 80 \mathrm{~km}$ & $500 \pm 25 \mathrm{~km}$ \\
\hline Asian velocity & $0 \mathrm{~cm} \cdot \mathrm{yr}-1$ & $<5$ cm.yr-1 & $<5.0->3.0$ cm.yr-1 & $2.6 \mathrm{~cm} . \mathrm{yr}-1$ \\
\hline Asian shortening & $0 \mathrm{~km}$ & $<250 \mathrm{~km}$ & $493 \pm 186$ & $622 \pm 110$ \\
\hline $\begin{array}{l}\text { Subsidence rate } \\
\text { Sedimentary facies } \\
\text { Sandstone petrography }\end{array}$ & $\begin{array}{l}\sim 0.02 \mathrm{~mm} . \mathrm{yr}-1 \\
\text { shelf sedim } \\
\text { quartzarenites }\end{array}$ & $\begin{array}{l}\sim 0.1 \mathrm{~mm} . \mathrm{yr}-1 \\
\text { deltaic redbeds } \\
\text { volc+ophio detritus }\end{array}$ & $\begin{array}{l}<0.01 \mathrm{~mm} . \mathrm{yr}-1 \\
\text { uncorformities } \\
\text {----- }\end{array}$ & $\begin{array}{l}>0.2 \mathrm{~mm} . \mathrm{yr}-1 \\
\text { fluvial molasse } \\
\text { metam detritus }\end{array}$ \\
\hline $\begin{array}{l}\text { Indian edge metamorphism } \\
\text { HHC metamorphism }\end{array}$ & $\begin{array}{l}\text { none } \\
\text { none }\end{array}$ & $\begin{array}{l}\text { eclogite facies } \\
\text { none }\end{array}$ & $\begin{array}{l}\text { amphibolite facies } \\
\text { granulite facies }\end{array}$ & $\begin{array}{l}\text { greenschist facies } \\
\text { anatexis }\end{array}$ \\
\hline Asian Margin & arc volcanism & cont sedim & uplift & uplift \\
\hline
\end{tabular}

Table 6: From subduction to collision dynamics in Himalaya 